\title{
Öğretmenlerin Mesleki Benlik Saygıları ile Psikolojik Danışma ve Rehberlik Hizmetlerine Yönelik Tutumları Arasındaki İlişki*
}

\section{The Relationship between Teachers' Professional Self-Esteem and Their Attitudes towards the Psychological Counseling and Guidance Services}

\author{
Fatih CAMADAN CA* $^{*}$, Selvi BAŞTOPÇU***, Günseli TOSUN****, \\ Nesrin YANGIN*****, Zeliha KILIÇ*******
}

\begin{abstract}
Öz: Bu çalışmanın amacı öğretmenlerin mesleki benlik saygıları ile psikolojik danışma ve rehberlik hizmetlerine yönelik tutumları arasındaki ilişkinin belirlenmesidir. Ayrıca öğretmenlerin psikolojik danışma ve rehberlik hizmetlerine yönelik tutumları çeşitli değişkenler açısından incelenmiștir. Nicel araştırma yaklaşımı çerçevesinde yürütülen bu araştırmanın çalışma grubunu anaokulu, ilkokul, ortaokul ve lisede görevli 427 öğretmen oluşturmaktadır. Araştırmada "Arıcak Mesleki Benlik Saygısı Ölçeği”" (Arıcak, 1999b), "Rehberlik ve Psikolojik Danışma Faaliyetlerine Yönelik Öğretmen Tutumları Ölçeği" (Abbasoğlu, 2014) ve "Kişisel Bilgi Formu" kullanılmıştır. Araştırma sonucunda mesleki benlik saygısı, cinsiyet ve psikolojik danışma ve rehberlik ile ilgili hizmet içi eğitim alma durumu değişkenlerinin birlikte psikolojik danışma ve rehberlik hizmetlerine yönelik tutum ile orta düzeyde anlamlı şekilde ilişkili olduğu ve değinilen değişkenlerin psikolojik danışma ve rehberlik hizmetlerine yönelik tutumun \% 11'ini açıkladığı anlaşılmıştır $\left(\mathrm{R}=.330, \mathrm{~F}_{(3-423)}=17.194, \mathrm{p}<.001\right)$. Regresyon katsayılarının anlamlılığı ile ilgili yapılan $\mathrm{t}$-testi sonuçları incelendiğinde ise yordayıcı değişkenlerden sadece mesleki benlik saygısı $(\beta=.269, \mathrm{p}<.001)$ ve psikolojik danışma ve rehberlik ile ilgili hizmet içi eğitim alma durumu $(\beta=.170, \mathrm{p}<$ .001) değişkenlerinin rehberliğe yönelik tutumu anlamlı şekilde açıkladığı sonucuna ulaşılmıştır.

Anahtar Kelimeler: Mesleki benlik saygısı, psikolojik danışma ve rehberlik hizmetlerine yönelik tutum, öğretmen
\end{abstract}

\begin{abstract}
The aim of this research is to determine the relationship between teachers' professional selfesteem and their attitudes towards the psychological counseling and guidance services. In addition, teachers' attitudes towards the psychological counseling and guidance services are searched in terms of various perspectives. This research was conducted on 427 teachers working at preschool, primary, secondary and high schools. In this research, "Arıcak Professional Self-Esteem Scale" (Arıcak, 1999b), "Teachers' Attitude Scale Concerning Guidance Service" (Abbasoğlu, 2014) and "Personal Information Form" were used in order to get some information about demographic features. At the end of the research, it was determined that professional self- esteem, gender and getting in-service training in psychological counseling and guidanceare related to the attitude towards the psychological counseling and guidance services. Also, it is understood that the mentioned elements explain 11 percent of the attitude towards the
\end{abstract}

\footnotetext{
*Bu çalışma Uluslararası Eğitimde Araştırmalar Kongresi'nde (13-15 Ekim 2016/Rize) sunulan sözlü bildirinin genişletilmiş halidir

${ }^{* *}$ Dr. Öğr. Üyesi, Recep Tayyip Erdoğan Üniversitesi, Eğitim Fakültesi, Çayeli/Rize, e-posta: fatih.camadan@erdogan.edu.tr

${ }^{* * *}$ Yüksek Lisans Öğrencisi, Recep Tayyip Erdoğan Üniversitesi, Sosyal Bilimler Enstitüsü, e-posta: selvibastopcu@gmail.com

**** Yüksek Lisans Öğrencisi, Recep Tayyip Erdoğan Üniversitesi, Sosyal Bilimler Enstitüsü, e-posta: gnsli@ hotmail.com

*****Yüksek Lisans Öğrencisi, Recep Tayyip Erdoğan Üniversitesi, Sosyal Bilimler Enstitüsü, e-posta: nesrinyangin@gmail.com

*******Yüksek Lisans Öğrencisi, Recep Tayyip Erdoğan Üniversitesi, Sosyal Bilimler Enstitüsü, e-posta:

zelihaolgun.8989@gmail.com
} 
psychological counseling and guidance services $\left(\mathrm{R}=.330, \mathrm{~F}_{(3-423)}=17.194, \mathrm{p}<.001\right)$. However, when $\mathrm{t}$-test results were examined, it was found out that only professional self-esteem $(\beta=.269, \mathrm{p}<.001)$ and getting in-service training in psychological counseling and guidance $(\beta=.170, p<.001)$ explains the attitude towards the psychological counseling and guidance significantly.

Keywords: Professional self-esteem, attitude towards the psychological counseling and guidance service, teacher

\section{Giriș}

Ülkeler ekonomik ve sosyal kalkınmalarını sahip oldukları insan gücü potansiyellerine borçludurlar. Bu potansiyellerini ekonomik ve sosyal kalkınmalarının kullanımına hazır hale getirmek için güçlü eğitim sistemlerine ihtiyaç duymaktadırlar. Eğitim sisteminin güçlenmesi genel olarak eğitici, eğitilen, amaç ve yöntemleri ile ülkenin her yerinde uygulanan ulusal bir felsefeyi temsil etmektedir (Arıcak, 1999a). Bu felsefenin etkisi ile dönüşen eğitim sistemlerinin, insanoğlunun tarihi kadar uzun bir geçmiş̧inin olduğu ifade edilebilir. Burada önemli görülen nokta, eğitim sistemlerinin toplumun yapısı ile birlikte bir değişim içerisinde olmasıdır. $\mathrm{Bu}$ değişimin sürdürülebilir olması ise eğitim sistemlerinin işlerlik kazanmasıyla ilgili bir durumdur.

Pehlivan'a (1993) göre bir eğitim sisteminin işlerlik kazanmasında öğretmenlik mesleğinin niteliği ve niceliğinin artırılmasının ve bu süreçteki standartların yükseltilmesinin önemli olduğu vurgulanmıştır. Bu konuda önemli görülen diğer bir durum, öğretmenlerin kişisel özellikleri ve mesleklerine yönelik algılarının mesleki performanslarını etkilemesidir (Özbek, Kahyaoğlu ve Özgen, 2007). Bu kapsamda öğretmenin, mesleğini geçinme ve benzeri kaygılardan uzak bir şekilde, severek ve önem vererek icra etmesi beklenmektedir. Ayrıca bu mesleğin gereklerine inanan bir öğretmenin, mesleğine karş1 olumlu duygu ve düşünceler beslemesi gerekmektedir. Bu özellikler mesleki benlik saygısı kapsamında ele alınmıştır (Sayın, 2003). Dolayısıyla öğretmenlerin mesleki benlik saygılarının, mesleklerinin gereklerini yerine getirmelerinde önemli bir değişken olduğu düşünülmektedir.

Çelikten, Şanal ve Yeni (2005), öğretmenlik mesleğinin rollerini temsilcilik, liderlik, öğreticilik, arabuluculuk, hakemlik ve rehberlik olarak sıralamıştır. Bu rollerden birisi olan rehberlik, kavram olarak Türk Milli Eğitim sistemine 1950'li yıllarda girmiş, anlayış ve uygulamada önemli değişikliklere sebep olmuştur (Kepçeoğlu, 1987). Günümüzde ise ögretmenlerin rehberlik rolü, profesyonel olarak psikolojik danışma ve rehberlik hizmetleri çerçevesinde yürütülmektedir. Dolayısıyla öğretmenlerin psikolojik danışma ve rehberlik hizmetlerine ilişkin görüşlerinin bu hizmetlerin sağlıklı şekilde sürdürülmesinde etkili olduğu değerlendirilmektedir (Gündüz, İnand1 ve Tunç, 2014). Bu bağlamda öğretmenlerin psikolojik danışma ve rehberlik hizmetlerine yönelik olumlu tutumlarının yapılacak faaliyetlerin verimliliği üzerinde etkisi olan bir değişken olduğu düşünülmektedir.

Yukarıda yapılan değerlendirmeler ışığında öğretmenlerin mesleki benlik saygıları ile psikolojik danışma ve rehberlik hizmetlerine yönelik tutumlarının sunulan eğitim hizmetlerinde etkili değişkenler olduğu anlaşılmaktadır. Değinilen bu değişkenlerin ayrıntılı şekilde açıklamasına aşağıda yer verilmiştir.

Benlik saygısı, bireyin kendine karşı geliştirdiği pozitif veya negatif duygu ve düşüncelerin bütünü olarak tanımlanmaktadır (Rosenberg, Schooler, Schoenbach ve Rosenberg, 1995). Baumeister, Campbell, Krueger ve Vohs (2003) yüksek benlik saygısını kişinin kendini olumlu değerlendirmesiyle; düşük benlik saygısını ise olumsuz değerlendirmesiyle ilgili görmüşlerdir. Bireyin mesleki yaşantılardaki kendisine ilişkin algısı ise mesleki benlik saygıs1 ile açıklanabilir. Mesleki benlik saygısı, bireyin önem verdiği kişilerden ve toplumun görüşlerinden etkilenerek şekillenen, tamamen spesifik ve bireye özgü bir tutumdur (Baloğlu, Karadağ, Çalışkan ve Korkmaz, 2006). Sayın, (2005) ise bu kavramı, bireyin mesleği ile ilgili olarak benliğine yüklediği açıklamalardan duyduğu sayg1 veya gururun düzeyi olarak tanımlamıştır. Dolayısıyla bireyin mesleğinden duyduğu memnuniyet ve mesleğini değerli görme derecesi yüksek ise mesleki benlik saygısı yüksek; düşük ise meslek benlik saygısı da bu doğrultuda düşük olarak değerlendirilmektedir. Bu konuyla ilgili olarak Ünal ve Şimşek (2008) 
mesleki benlik saygısının düşük olduğu durumda icra edilen bir mesleğin ne topluma ne de bireye yararının olmadığını ifade etmiştir.

Mesleki benlik saygısı kavramı her meslekte olduğu gibi öğretmenlik mesleği açısından da önemlidir. LoVette'e (1997) göre öğretmenlerin, öğrencilerinde olumlu davranışlar geliştirebilmeleri için öncelikle kendilerinin bu davranışlara sahip olması gerekmektedir. Bu bağlamda öğretmenlerin değinilen bu davranışlara sahip olmaları mesleklerine ilişkin olumlu bir algı geliştirmeleri ile ilgili görülmektedir. Bu durum mesleki benlik saygısı ile bağdaştırılabilir. Benzer şekilde Arıcak (1999a), bir öğretmenin mesleğinin gereklerini benimsemiş olmasının, mesleğine karşı olumlu tutum geliştirdiğinin göstergesi olduğunu dile getirmiştir. Ayrıca öğretmenin mesleki benlik saygısının yüksek olmasının, o öğretmenin mesleğinde başarılı ve verimli olmasında etkili bir faktör olduğuna değinmiştir.

Öğretmenlerin mesleki benlik saygıları konusunda yapılan araştırmalar incelendiğinde çeşitli sonuçlara ulaşılmıştır. Bu araştırmalarda mesleki benlik saygısı ile benlik saygısı (Kutlu ve Soğukpınar, 2015), meslekteki performans (Roe ve Gray, 1991), sabır, empati ve dinleme becerileri (Glotova ve Wilhelm, 2014), içsel ve dişsal iş doyumu (Baloğlu ve diğerleri, 2006), öz yeterlik (Öztürk, 2008), mesleğe yönelik tutum (Abbasoğlu ve Öncü, 2013; Zoroğlu, 2014), akademik iyimserlik (Biroğul ve Deniz, 2015), sosyal sorumluluk paylaşma davranışı (Dilmaç ve Ekşi, 2012), yaşam doyumu (Er, 2017), mesleğe yönelik yetkinlik (Gündem, 2009) ve mesleki haz (Bozali ve Camadan,2018) arasında olumlu yönde anlamlı ilişkilerin olduğu görülmüştür. Bununla birlikte mesleki benlik saygisı ile umutsuzluk, depresyon ve olumsuz düşünceler (Jan, Khan, Khan, Khan ve Saif, 2015) ve tükenmişlik (Friedman ve Farber, 1992) arasında olumsuz yönde anlamlı ilişkilerin olduğu belirlenmiştir.Yapılan bazı araştırmalarda ise mesleki benlik saygısı çeşitli demografik değişkenler açısından incelenmiştir. Bu demografik değişkenlerden birisi cinsiyettir. Mesleki benlik saygısı açısından kadınların lehine sonuçlar olduğu gibi (Tabassum ve Ali, 2012; Ünal ve Şimşek, 2008), erkeklerin lehine sonuçlar da bulunmaktadır (Yıldırım, Kırımoğlu ve Temiz, 2010). Bazı araştırmalarda ise cinsiyete dayalı farklılaşma görülmemiştir (Dursun, Çuhadar ve Tanyeri,2014; Kutlu ve Soğukpınar, 2015). Bir diğer değişken olan branşın dikkate alındığı çalışmaların bazılarında mesleki benlik saygısının bu değişkene göre farklılık gösterdiği (Sayın, 2003), bazılarında ise herhangi bir farklılık göstermediği (Ünal ve Şimşek, 2008) saptanmıştır. Öğretmenlerin hizmet y1lı göz önünde bulundurularak yapılan karşılaştırmalarda ise mesleki benlik saygısının bu değişkene göre farklılaşmadığı bulunmuştur (Kutlu ve Soğukpınar, 2015; Sarı, 2016).

Öğretmenlerin mesleki benlik saygıları ile ilişkili olduğu düşünülen psikolojik danışma ve rehberlik hizmetlerine yönelik tutumun anlaşılabilmesi için psikolojik danışma ve rehberlik hizmetlerinin eğitim sistemi içerisindeki yeri ve önemi anlaşılmalıdır. Eğitim sisteminin temel amacı, çocuklarda sadece akademik başarıyı teşvik etmek değil bütünsel gelişimlerini desteklemektir (Panja ve Krishna De, 2015). Çağdaş eğitimi oluşturan başlıca unsurlar öğretim, yönetim ve öğrenci kişilik hizmetleri olarak kabul edilmektedir. Öğrenci kişilik hizmetlerinden biri olan rehberlik hizmetlerinde bireye yardım edilmesi amaçlanmakta ve birey merkeze alınmaktadır (Karataş ve Şahin Baltacı, 2013). Bu amaç çerçevesinde bireyin "ben kimim?", "ne olmak istiyorum?", "ne olmalıyım?", "yeterli ve yetersiz yönlerim nelerdir?" gibi sorulara cevap bulmasından (Özoğlu, 1977), meslek tanıtımlarından, verimli ders çalışma teknikleri hakkında bilgilendirmeye kadar birçok alanda öğrencilere yardım edilmektedir (Gazioğlu ve İlgar, 2008).

Psikolojik danışma ve rehberlik hizmetleri sadece psikolojik danışman tarafından yürütülen bir faaliyet olmayıp (Bülbül, 2009), öğretmenlerin de bu hizmetleri gerçekleştirecek ekibin önemli bir parçası olduğu kabul edilmektedir (Çam, 2004). Nitekim Milli Eğitim Bakanlığı Rehberlik ve Psikolojik Danışma Hizmetleri Yönetmeliği’nde (2001) belirtildiği üzere okul müdürü, müdür yardımcısı, psikolojik danışman ve öğretmenlerin her birinin psikolojik danışma ve rehberlik hizmetlerinde farklı görev ve sorumluluklarının olduğu ayrıntılı şekilde açıklanmıştır. Dolayısıyla değinilen paydaşların psikolojik danışma ve rehberlik hizmetleri ile ilgili geliştirdikleri anlayışın önemli olduğu düşünülmektedir. Demir ve Can'ın (2015) ifade ettiği üzere bu hizmetlere yönelik olumlu anlayış, rehberlik ekibindeki bireylerin verimli ve işbirliği içerisinde çalışabilmelerinde etkili bir faktördür. Bu bağlamda öğretmenlerin 
rehberlik faaliyetlerine yönelik olumlu bir tutuma sahip olmalarının gerekliliği (Teker, 2007), olumsuz tutumlarının ise yürütülen hizmetlerin verimliliğini olumsuz yönde etkileyeceği ifade edilmiştir (Abbasoğlu, 2014). Benzer şekilde, öğretmenlerin okullarındaki psikolojik danışma ve rehberlik hizmetlerine ilişkin tutumlarının pozitif, nötr veya negatif yönde değişebildiği ve bu tutumlarının öğretmenlerin bu hizmetlere aktif katılımlarına en çok etki eden faktörlerden olduğu kabul edilmiştir (Owino ve Odera, 2014a). Aynı zamanda öğretmenlerin psikolojik danışma ve rehberlik hizmetlerine yönelik olumlu tutumunun öğrencilerin gelişimlerinde kayda değer etkilerinin olduğu ifade edilmiştir (Bülbül, 2009).

Psikolojik danışma ve rehberlik hizmetleri ile ilgili yapılan bir takım araştırmalarda öğretmenlerin bu hizmetlere ilişkin olumlu bir algıya sahip olduğu belirlenmiştir (Akgün, 2010; Cooper, Hough ve Loynd, 2005; Gündüz ve diğerleri, 2014; Pershing ve Demetropoulos, 1981). $\mathrm{Bu}$ konuda yapılan bazı araştırmalarda ise öğretmenlerin rehberlik hizmetlerine ilişkin olumlu tutumları ile rehberlik hizmetlerine ilişkin olumlu anlayışları arasında olumlu yönde bir ilişki olduğu bulunmuştur (Demir ve Can, 2015; Yerlikaya, Sak ve Şahin Sak, 2014; Yumrutaş, 2006). Psikolojik danışma ve rehberlik hizmetlerine yönelik tutumun incelendiği araştırmalarda demografik değişkenlerin de dikkate alındığı görülmüştür. Cinsiyet değişkeninin dikkate alındığ1 bazı araştırmalarda kadınların (Demir ve Can, 2015), bazılarında ise erkeklerin (McPhee, 1985) tutumlarının daha olumlu olduğu sonucuna ulaşılmışken; cinsiyet açısından anlamlı bir farklılığın olmadığı çalışmalara da rastlanmıştır (Gündüz ve diğerleri, 2014; Onur, 1997; Yumrutaş, 2006). Öğretmenlerin psikolojik danışma ve rehberlik hizmetlerine ilişkin tutumlarının branş (Demir ve Can, 2015; Onur, 1997), hizmet yılı (Demir ve Can, 2015; Gündüz ve diğerleri, 2014; Yumrutaş, 2006) ve okulda çalışan psikolojik danışman sayısı açısından (Gündüz ve diğerleri, 2014) incelendiği çalışmalarda tutumlarının bu değişkenlere göre anlamlı farklılık göstermediği ortaya konulmuştur. Ayrıca yapılan araştırmalarda öğretmenlerin psikolojik danışma ve rehberlik hizmetlerine yönelik hizmet içi eğitim almalarının psikolojik danışma ve rehberlik hizmetlerine ilişkin tutumlarını olumlu yönde etkilediği ortaya konulduğu gibi (Demir ve Can, 2015; Onur, 1997), tutumun eğitim alıp almamaya göre herhangi bir farklılık göstermediğine dair bulgulara da ulaşılmıştır (Masibi, 1995).

İlgili literatür taraması sonucunda öğretmenlerin mesleki benlik saygılarının ve psikolojik danışma ve rehberlik hizmetlerine yönelik olumlu tutumlarının yüksek oluşunun çeşitli olumlu sonuçlara yol açtı̆̆ $\breve{g}_{1}$ anlaşılmıştır. Bu değerlendirmeden hareketle değinilen değişkenlerin birbiriyle de ilişkili olduğu tahmin edilmiştir. Tahmin edilen bu ilişki bu çalışma kapsamında incelenmeye değer görülmüştür. Atıcı, Özyürek ve Çam (2005) tarafından yapılan bir araştırmada psikolojik danışman adaylarının okul danışmanlığı uygulamalarına ilişkin yetkinlik algıları ile mesleki benlik saygıları arasındaki ilişki incelenmiş ve bu değişkenler arasında olumlu yönde anlamlı bir ilişkinin olduğu belirlenmiştir. Dolayısıyla özyeterlik algısı ile mesleki benlik saygısı değişkenlerinin birbiriyle ilişkili olduğu anlaşılmıştır. Ancak ilgili alan yazında mesleki benlik saygısı ile psikolojik danışma ve rehberlik hizmetlerine yönelik tutum arasındaki ilişkinin öğretmenler açısından incelendiği herhangi bir araştırmaya rastlanmamıştır. Ayrıca öğretmenlerin mesleki benlik saygılarının ve psikolojik danışma ve rehberlik hizmetlerine yönelik tutumlarının incelendiği araştırmalarda çeşitli demografik değişkenlerin de dikkate alındığı görülmüştür. Dolayısıyla psikolojik danışma ve rehberlik hizmetlerine yönelik tutumun anlaşılması amacıyla yapılan araştırmalarda psikolojik değişkenler ile birlikte demografik değişkenlerin de dikkate alınmasının gerekli olduğu düşünülmüştür. İlgili literatürde bu konuda yapılan herhangi bir çalışmaya rastlanmadığından bu araştırmadan elde edilen sonuçların alan yazındaki boşluğu doldurmaya katkısının olacağ değerlendirilmektedir. Okullarda rehberlik faaliyetleri kapsamında her sınıf için bir sınıf rehber öğretmeni tayin edilmektedir. Belirlenen sınıf rehber öğretmeni, sınıfının rehberlik hizmetlerinin yürütülmesinden doğrudan sorumlu olan kişidir (Milli Eğitim Bakanlığı Rehberlik ve Psikolojik Danışma Hizmetleri Yönetmeliği, 2001). Bu yönüyle öğretmenlerin rehberlik faaliyetleri içerisinde oldukça önemli bir rolünün olduğu anlaşılmaktadır. Bu kapsamda öğretmenlerin psikolojik danışma ve rehberlik hizmetlerine yönelik tutumunun olumlu ya da 
olumsuz yönde olmasının yapacakları çalışmaları etkileyebileceğinden, bu tutumları üzerinde etkisi olan faktörlerin belirlenmesinin önemli olduğu düşünülmektedir.Bu bağlamda araştırmada öğretmenlerin mesleki benlik saygıları ile psikolojik danışma ve rehberlik hizmetlerine yönelik tutumları arasındaki ilişkinin belirlenmesi amaçlanmış olup bu amaç çerçevesinde aşağıdaki problem cümlelerine cevap aranmıştır.

1. Öğretmenlerin mesleki benlik saygıları ve psikolojik danışma ve rehberlik hizmetlerine yönelik tutumları ne düzeydedir?

2. Araştırmanın bağımsız değişkenleri (mesleki benlik saygısı, cinsiyet, hizmet yılı, okulunda psikolojik danışman bulunup bulunmadığı ve psikolojik danışma ve rehberlik ile ilgili hizmet içi eğitim alma durumu) ile psikolojik danışma ve rehberlik hizmetlerine yönelik tutum arasında ilişki varmıdır?

3. Araştırmanın bağımsız değişkenleri (mesleki benlik saygısı, cinsiyet, psikolojik danışma ve rehberlik ile ilgili hizmet içi eğitim alma durumu) psikolojik danışma ve rehberlik hizmetlerine yönelik tutumu yordamaktamıdır?

\section{Yöntem}

Bu bölümde araştırmanın modeli,çalışma grubu, veri toplama araçları, işlem ve verilerin analizi başlıklarına yer verilmiştir. Değinilen başlıkların altında yer alan bilgiler detaylarıyla aşağıda sunulmuştur.

\section{Araştırma modeli}

$\mathrm{Bu}$ araştırmada değişkenler arasındaki ilişkiyi belirlemeyi amaçlayan ilişkisel tarama yöntemi kullanılmıştır. İlişkisel tarama yöntemine dayalı araştırmalarda iki ya da daha çok değişken arasındaki ilişkilerin belirlenmesi ve neden-sonuç ile ilgili durumların ortaya çıkarılması amaçlanır (Büyüköztürk, Çakmak, Akgün, Karadeniz ve Demirel, 2014). Bu bağlamda çalışmada öğretmenlerin psikolojik danışma ve rehberlik hizmetlerine yönelik tutumları ile mesleki benlik saygıları, cinsiyetleri, hizmet yılları, okullarında psikolojik danışman bulunup bulunmaması ve psikolojik danışma ve rehberlik ile ilgili hizmet içi eğitim alma durumu arasındaki ilişki ele incelenmiştir.

\section{Çalışma grubu}

Araştırmanın çalışma grubu; 2015-2016 eğitim-öğretim yılında Rize il merkezinde görev yapan öğretmenlerden oluşmaktadır. Katılımcılara ilişkin tanımlayıcı bilgiler Tablo 1'de sunulmuştur.

Tablo 1.

Katılımcılara İlişkin Tanımlayıcı Bilgiler

\begin{tabular}{lccc}
\hline Değişken & Türü & $\mathrm{n}$ & $\%$ \\
\hline Cinsiyet & Kadın & 282 & 66 \\
& Erkek & 145 & 34 \\
\hline \multirow{2}{*}{ Öğretim basamağ1 } & Okulöncesi & 119 & 27.9 \\
& Illkokul & 95 & 22.2 \\
& Ortaokul & 100 & 23.4 \\
& Lise & 113 & 26.5 \\
\hline Okulunda psikolojik danışman bulunup bulunmadı̆̆ı & Var & 291 & 68.1 \\
& Yok & 136 & 31.9 \\
\hline Psikolojik danışma ve rehberlik ile ilgili hizmetiçi eğitim alma durumu & Evet & 194 & 45.4 \\
& Hayır & 233 & 54.6 \\
\hline Hizmet y1lı & $1-25$ yıl & 427 & 100 \\
\hline Toplam & & 427 & 100 \\
\hline
\end{tabular}


Tablo 1'e göre kat1lımc1ların 282'si kadın ( $\%$ 66) ve 145'i erkektir (\% 34). Kat1lımciların 119'u okul öncesi (\% 27.9), 95'i ilkokul (\% 22.2), 100'ü ortaokul (\% 23.4) ve 113 'ü lisede (\% 26.5) görev yapmaktadır. Katılımcıların çalıştıkları okulların 291'inde (\% 68.1) psikolojik danışman bulunduğu; 136'sında (\% 31.9) bulunmadığı görülmektedir. Katılımcıların 194'ünün (\% 45.4) psikolojik danışma ve rehberlik ile ilgili hizmet içi eğitim aldıkları; 233 'ünün (\% 54.6) ise almadıkları anlaşılmaktadır. Katılımcılar hizmet y1lı açısından incelendiğinde 1 yıl ile 25 yıl arasında görev yaptıkları anlaşılmaktadır.Toplamda araştırmaya 427 öğretmen katılmıştır. Branş açısından değerlendirildiğinde ise anaokulunda; okul öncesi öğretmeni, ilkokulda; sınıf, İngilizce ve din kültürü ve ahlak bilgisi, ortaokulda; fen bilimleri ve teknoloji, sosyal bilgiler, ilköğretim matematik, Türkçe, Arapça, Almanca, beden eğitimi, müzik ve görsel sanatlar; lisede ise; fizik, biyoloji, kimya, coğrafya, tarih, felsefe, Türk dili ve edebiyatı ve ortaöğretim matematik olmak üzere toplam 21 farklı branştan öğretmen araştırmada yer almıştır.

\section{Veri toplama araçları}

Araştırmada öğretmenlerin mesleki benlik saygılarını belirlemede "Arıcak Mesleki Benlik Saygısı Ölçeği”", rehberlik ve psikolojik danışma faaliyetlerine yönelik tutumlarını belirlemede "Rehberlik ve Psikolojik Danışma Faaliyetlerine Yönelik Öğretmen Tutumları Ölçeği” ve bazı demografik özellikleri hakkında bilgi toplamak amacıyla "Kişisel Bilgi Formu" kullanılmıştır.

\section{Arıcak Mesleki Benlik Saygısı Ölçeği}

Arıcak Mesleki Benlik Saygısı Ölçeği, Arıcak (1999b) tarafından geliştirilmiştir. 5'li Likert tipinde geliştirilen ölçme aracı, kesinlikle katılıyorum: 1, katılmıyorum: 2, kararsızım: 3, katılıyorum: 4 ve tamamen katılıyorum: 5 olacak şekilde puanlanmaktadır. Ölçek 14'ü olumlu $(2,5,7,9,11,13,14,16,18,20,24,26,28$ ve 30$)$ ve 16 's1 olumsuz $(1,3,4,6,8,10,12,15,17$, $19,21,22,23,25,27$ ve 29) olmak üzere toplam 30 maddeden oluşmaktadır. Olumsuz maddeler tersten puanlanmaktadır. Ölçeğin toplam puanı hesaplanabilmekte olup alınan puanların yükselmesi, bireylerin mesleki benlik saygılarının yükseldiği şeklinde yorumlanmaktadır. Ölçekten alınabilecek en yüksek puan 150 ve en düşük puan 30'dur. Bu araştırma kapsamında ölçeğin toplam puanı dikkate alınmıştır. Ölçeğin geçerliğinin test edilmesinde kapsam geçerliği ve yapı geçerliği incelenmiştir. Ölçeğin maddelerine ilişkin görüşü alınan uzmanların \% 75 'inin uygun gördügü maddeler ölçeğe dâhil edilmiştir. Bu sayede kapsam geçerliği sağlanmaya çalışılmıştır.Yapı geçerliğinin test edilmesinde ise açımlayıcı faktör analizi yapılmıştır. Ölçeğin tek boyutlu yapısına ilişkin açıklanan varyans \% 59.37 olarak hesaplanmıştır. Bu sonuca dayalı olarak ölçeğin yapı geçerliğinin sağlandığ 1 kabul edilmiştir. Ölçeğin güvenirliği için hesaplanan Cronbach $\alpha$ güvenirlik katsayısı .93 olarak bulunmuştur. Yapılan analizler sonucunda ölçme aracının geçerli ve güvenilir bir ölçek olarak kullanılabileceğine karar verilmiştir.

\section{Rehberlik ve Psikolojik Danışma Faaliyetlerine Yönelik Tutum Ölçeği}

Rehberlik ve Psikolojik Danışma Faaliyetlerine Yönelik Tutum Ölçeği, Abbasoğlu (2014) tarafından geliştirilmiştir. 5'li Likert tipinde geliştirilen ölçeğin puanlaması kesinlikle katılıyorum: 5, katılıyorum: 4, kararsızım: 3, katılmıyorum: 2, kesinlikle katılmıyorum: 1 şeklindedir. Ölçek 17 maddeden oluşmakta ve tersten puanlanan madde içermemektedir. Ölçek geliştirici etki, akademik ilgi ve rehberlik etkinliklerine katılım olmak üzere üç boyutlu olup toplam puanı hesaplanarak da kullanılabilmektedir. Ölçekten alınan puanların yükselmesi, rehberlik ve psikolojik danışma faaliyetlerine yönelik tutumun da olumlu yönde arttığı anlamına gelmektedir. Ölçekten alınabilecek en düşük puan 17, en yüksek puan ise $85^{\prime}$ tir. Bu araştırmada ölçek toplam puanı hesaplanarak kullanılmıştır. Ölçeğin geçerliği test edilmesinde faktör analizi yapılmıştır. Faktörlerin açıkladıkları toplam varyans \%69.35 olarak hesaplanmıştır. Ölçeğin güvenirliği için hesaplanan Cronbach $\alpha$ güvenirlik katsayıları şu şekildedir; geliştirici etki: .94, akademik ilgi: .80, rehberlik hizmetlerine katılım: .70 ve ölçeğin toplamı: .92. Pearson analizi sonucunda madde-toplam, madde-kalan ve faktörler arasındaki korelasyonların anlamlı olduğu bulunmuştur. Bununla birlikte ölçeğin iki hafta arayla uygulanan formlarının alt boyut ve 
toplam puanları arasında da anlamlı korelasyon değerleri olduğu saptanmıştır. Ayrıca maddelerin alt-üst \%27'lik puanları üzerinde yapılan t-testi sonucunda faktörlerin ayırt edici olduğu belirlenmiştir. Yapılan bu analizler sonucunda ölçme aracının geçerli ve güvenilir olduğu görüşüne varılmıştır.

\section{Kişisel Bilgi Formu}

Araştırmaya katılan öğretmenlerin bazı özellikleri hakkında bilgi toplamak amacıyla araştırmacılar tarafindan "Kişisel Bilgi Formu" geliştirilmiştir. Bu formda cinsiyet, çalışılan kurumun öğretim basamağ psikolojik danışma ve rehberlik ile ilgili hizmet içi eğitim alma durumu ve branş değişkenleri ile ilgili bilgiler elde edilmiştir.

\section{İşlem}

Ölçme araçlarının uygulanması sürecinde öncelikle ölçekleri geliştiren araştırmacılardan kullanım izinleri ve milli eğitim müdürlügünden uygulama izinleri alınmıştır. Ölçme araçları farklı ögretim basamaklarından (okul öncesi, ilkokul, ortaokul ve lise) toplam 430 öğretmene uygulanmıştır. Uygulamalarda öğretmenler okullarında ziyaret edilmiş, ölçme araçları kendilerine ulaştırılmış ve bireysel olarak doğrudan araştırmacılar tarafindan uygulanarak toplanmıştır. Ölçme araçlarının doldurulması yaklaşık $20 \mathrm{dk}$. sürmüştür. Eksik doldurulan 3 tane ölçme aracı araştırmanın sonucunu olumsuz etkileyebileceğinden ötürü çalışmadan çıkarılmışıı. Dolayısıyla araştırmanın analizleri 427 veri üzerinden gerçekleştirilmiştir.

\section{Verilerin analizi}

$\mathrm{Bu}$ araştırma kapsamında temel olarak öğretmenlerin mesleki benlik saygıları ile psikolojik danışma ve rehberlik hizmetlerine yönelik tutumları arasındaki ilişki incelenmiştir. Araştırmanın birinci problem cümlesi olan; "öğretmenlerin mesleki benlik saygıları ve psikolojik danışma ve rehberlik hizmetlerine yönelik tutumları ne düzeydedir?"in cevaplanmasına yönelik olarak araştırmanın değişkenlerine ilişkin tanımlayıcı bilgiler ortaya çıkarılmıştır. $\mathrm{Bu}$ kapsamda değişkenlerin aritmetik ortalama ve standart sapma değerleri hesaplanmıştır. Araştırmanın ikinci problem cümlesi olan; "araştırmanın bağımsız değişkenleri (mesleki benlik saygısı, cinsiyet, hizmet yılı, okulunda psikolojik danışman bulunup bulunmadığ 1 ve psikolojik danışma ve rehberlik ile ilgili hizmet içi eğitim alma durumu) ile psikolojik danışma ve rehberlik hizmetlerine yönelik tutum arasında ilişki var mıdır?"ın cevaplanmasına yönelik olarak basit korelasyon analizi gerçekleştirilmiştir. Araştırmanın üçüncü problem cümlesi olan; "araştırmanın bağımsız değişkenleri (mesleki benlik saygısı, cinsiyet ve psikolojik danışma ve rehberlik ile ilgili hizmet içi eğitim alma durumu) psikolojik danışma ve rehberlik hizmetlerine yönelik tutumu yordamaktamıdır?"ın cevaplanmasına yönelik olarak çoklu doğrusal regresyon analizi gerçekleştirilmiştir. Verilerin analizinde cinsiyet, okulunda psikolojik danışman bulunup bulunmadığı ve psikolojik danışma ve rehberlik ile ilgili hizmet içi eğitim alma durumu, dummy (kukla) değişken olarak düzenlenmiştir. Büyüköztürk'ün (2009) değindiği gibi sınıflama ölçeğinden elde edilen değişkenlerin bağımlı değişken üzerindeki etkisi incelenmek istendiğinde; sınıflamalı değişkenin düzeylerinden biri dışarıda tutularak düzey sayısının bir eksiği kadar üretilen değişkene dummy değişken denmektedir. Belirlenen bu değişken ile analizlerin gerçekleştirilebileceği ifade edilmiştir. Elde edilen veriler SPSS 22.0 paket programı ile analiz edilmiştir.

Yukarıda değinilen çoklu doğrusal regresyon analizi yapılmadan önce bu analiz için gerekli görülen varsayımların sağlanıp sağlanmadığı kontrol edilmiştir. Gerekli koşulların sağlandığı anlaşıldıktan sonraanalizler gerçekleştirilmiştir. Değinilen varsayımlar tekli normallik, çoklu normallik, çoklu bağlantı problemi (multi-colinearity), otokorelasyon ve doğrusallıktır.

Değişkenlerin tekli normal dağılıma sahip olup olmadıklarının belirlenmesi amacıyla çarpıklık (skewness) ve basıklık (kurtosis) katsayısı değerleri hesaplanmıştır. Bu analizde cinsiyet ve psikolojik danışma ve rehberlik ile ilgili hizmet içi eğitim alma durumu dummy 
değişken olarak analize dâhil edilmiştir. Hesaplanan değerler bir takım betimleyici istatistik sonuçları ile birlikte Tablo 2'de sunulmuştur.

Tablo 2.

Araştırmanın Değişkenlerine İlişkin Betimleyici İstatistikler ile Çarpıklık (Skewness) ve Basıklık (Kurtosis) Katsayıları

\begin{tabular}{lcc}
\hline Değişken & Çarpıklık (Skewness) & Basıklık (Kurtosis) \\
\hline Pdrhyt & -.286 &, 826 \\
Mbs & -.140 & -.713 \\
Cinsiyet (Kadın) & -.680 & -1.545 \\
Pdrihead (Evet) & .184 & -1.975 \\
\hline
\end{tabular}

Pdrhyt: Psikolojik danışma ve rehberlik hizmetlerine yönelik tutum, Mbs: Mesleki benlik saygısı, Pdrihead: Psikolojik danışma ve rehberlik ile ilgili hizmet içi eğitim alma durumu

Değişkenlerin normal dağılım gösterebilmesi için çarpıklık katsayısının |3|'ten; basıklık katsayısının ise |10|'dan küçük olması gerekmektedir (Kline, 2011). Tablo 2 incelendiğinde araştırmanın değişkenlerinin basıklık ve çarpıklık katsayılarının değinilen değerlerden küçük olduğu görülmektedir. Dolayısıyla değişkenlerin tekli normalliğe sahip olduğu söylenebilir.

Çoklu doğrusal regresyon analizinin yapılabilmesi için kontrol edilen diğer bir varsayım değişkenlerin çoklu normalliğe sahip olup olmadıklarıdır. Bu amaçla Mahalonobis uzaklık değeri hesaplanarak değişkenlerin uç değerlere sahip olup olmadığı belirlenmeye çalışılmıştır. Belirlenen bu uç değerlerin veri setinden çıkarılması önerilmektedir (Can, 2013). Araştırmada bir bağımlı değişken, üç bağımsız değişkenin olduğu dikkate alındığında Kay Kare $\left(\mathrm{x}^{2}\right)$ dağılım tablosunda 0.01 anlamlllık düzeyine denk gelen serbestlik derecesi (sd) değerinin 11.34 olduğu görülmektedir (Laurencelle ve Dupuis, 2002). Yapılan analiz sonucunda değişkenlerin Mahalonobis değeri, yukarıda değinilen tablo değerinden yüksek olan herhangi bir değerin olmadığı görülmüştür. $\mathrm{Bu}$ sayede değişkenlerin çoklu normalliğe sahip oldukları kabul edilmiştir.

Çoklu doğrusal regresyon analizinin yapılabilmesi için kontrol edilen diğer bir varsayım değiş̧kenler arasındaki ilişkilerin düzeyidir. $\mathrm{Bu}$ bağlamda bağımsız değişkenler arasındaki ilişkiyle ilgili olarak çoklu bağlantı (multicollinarity) probleminin olup olmadığı test edilmiştir. Değişkenler arasındaki korelasyonun.90'ın üzerinde olması durumunda çoklu bağlantı probleminin olduğu kabul edilmektedir (Şencan, 2005). Bu amaçla öncelikle bağımsız değişkenler arasındaki korelasyonlar hesaplanmıştır. Sonuçta değişkenler arasındaki korelasyon katsayılarının -.031 ile -.341 arasında değiştiği bulunmuştur (Tablo 4). Bu sonuçlara göre değişkenler arasındaki ilişkinin .90 'dan düşük olduğu dolayısıyla çoklu bağlantı probleminin olmadığı anlaşılmıştır. Ayrıca çoklu bağlantı probleminin sınanması için Varyans Büyütme Faktörü (VIF) ve Tolerans Değeri (TV) hesaplanmıştır. Çoklu bağlantı probleminin olmaması için VIF değerinin 10'dan küçük; TV'nin de 0.2'den büyük olması gerekmektedir (Field, Miles ve Field, 2009). Hesaplanan VIF ve TV değerlerine ilişkin elde edilen sonuçlar Tablo 5'te sunulmuştur. $\mathrm{Bu}$ değerlere göre değişkenler arasında çoklu bağlantı probleminin olmadığı anlaşılmıştır.

Çoklu doğrusal regresyon analizinin yapılabilmesi için bağımsız değişkenler arasında otokorelasyonun olup olmadığ kontrol edilmiştir. Bu amaçla Durbin Watson katsayısı hesaplanmıştır. $\mathrm{Bu}$ değerin 1.5 ile 2.5 arasında olması beklenmektedir (Kalayc1, 2009). Hesaplanan Durbin-Watson katsayısı değerinin 1.961 olduğu dolayısıyla değişkenler arasında otokorelasyon olmadığ 1 anlaşılmıştır (Tablo 5).

Test edilen varsayımlardan birisi de bağımsız değişkenler ile bağımlı değişken arasında doğrusal bir ilişkinin olup olmadığı ve puanların normal dağılım gösterip göstermediğidir. Bunların belirlenmesi amacıyla oluşturulan grafik Şekil 1'de sunulmuştur. 

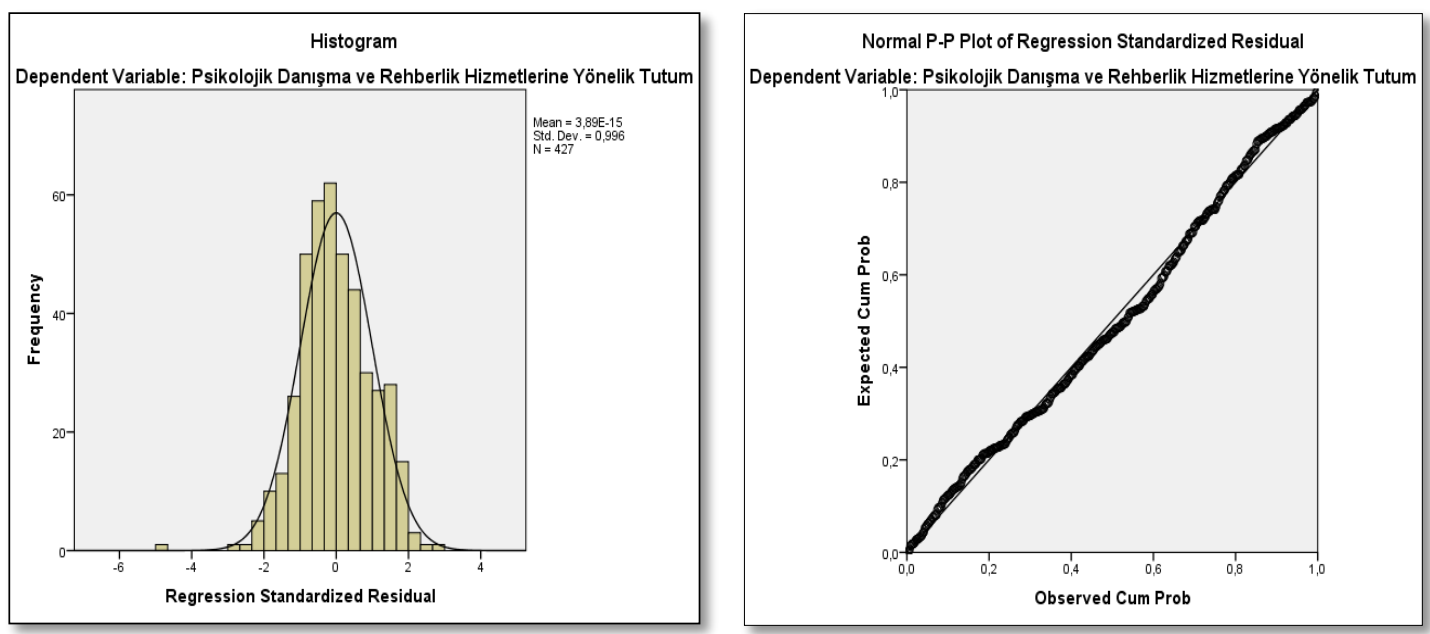

Şekil 1. Psikolojik Danışma ve Rehberlik Hizmetlerine Yönelik Tutum ve Bağımsız Değişkenlere İlişkin Histogram Grafiği, Saçılma Diyagramı ve Regresyon Doğrusu

Şekil 1 incelendiğinde yordayıcı değişkenler (mesleki benlik saygısı, cinsiyet ve psikolojik danışma ve rehberlik ile ilgili hizmet içi eğitim alma durumu) ile yordanan değişken olan psikolojik danışma ve rehberlik hizmetlerine yönelik tutuma ilişkin oluşturulan histogram ve saçılma diyagramlarında doğrusal bir ilişkinin olduğu ve noktaların bir eksen etrafında kümelendiği görülebilmektedir. Değinilen grafikler dikkate alındığında değişkenler arasında doğrusal bir ilişkinin olduğu ve puanların normal dağılım gösterdiği ifade edilebilir (Field ve diğerleri, 2009).

Yukarıda çoklu doğrusal regresyon analizinin yapılabilmesi için gerekli görülen varsayımların sağlanıp sağlanmadığı kontrol edilmiştir. Değinilen varsayımların sağlandığ anlaşıldıktan sonra bağımsız değiş̧kenlerinin bağımlı değişkeni ne şekilde yordadığının belirlenmesine yönelik çoklu doğrusal regresyon analizi gerçekleştirilmiştir.

\section{Bulgular}

$\mathrm{Bu}$ bölümde araştırmanın amacı ve bu amaç doğrultusunda oluşturulan problem cümlelerinin cevaplanmasına ilişkin gerçekleştirilen analizler sonucunda elde edilen bulgulara sırasıyla yer verilmiştir. Elde edilen bulgular; "öğretmenlerin mesleki benlik saygılarının ve psikolojik danışma ve rehberlik hizmetlerine yönelik tutumlarının düzeyi", "araştırmanın bağımsız değişkenleri ile psikolojik danışma ve rehberlik hizmetlerine yönelik tutumları arasındaki ilişki”, "araştırmanın bağımsız değişkenlerinin psikolojik danışma ve rehberlik hizmetlerine yönelik tutumu yordaması" şeklindedir. Değinilen bulgular aşağıda sunulmuştur.

\section{Öğretmenlerin mesleki benlik saygılarının ve psikolojik danışma ve rehberlik hizmetlerine yönelik tutumlarının düzeyi}

Araştırmanın birinci problem cümlesi olan "öğretmenlerin mesleki benlik saygıları ve psikolojik danışma ve rehberlik hizmetlerine yönelik tutumları ne düzeydedir?"'in cevaplanmasına yönelik olarak değişkenlere ilişkin tanımlayıcı bilgilere ulaşılmıştır. Elde edilen bilgiler Tablo 3'te sunulmuştur.

Tablo 3.

Değişkenlere İlişkin Tanımlayıcı İstatistikler

\begin{tabular}{lcc}
\hline Değişkenler & $\bar{X}$ & Ss \\
\hline Mesleki benlik saygıı1 & 4.815 & .634 \\
\hline Psikolojik danışma ve rehberlik hizmetlerine yönelik tutum & 2.802 & .320 \\
\hline
\end{tabular}


Tablo 3 incelendiğinde öğretmenlerin mesleki benlik saygılarının aritmetik ortalamasının 5 maksimum puan üzerinden 4.815 (Ss:.634) ve psikolojik danışma ve rehberlik hizmetlerine yönelik olumlu tutumlarının aritmetik ortalamasının 5 maksimum puan üzerinden 2.802 (Ss:.320) olduğu görülmektedir. Araştırmada kullanılan ölçeklerin 5'li Likert tipinde geliştirildikleri göz önünde bulundurulduğunda katılımcıların mesleki benlik saygılarının ortalama puanın üzerinde; psikolojik danışma ve rehberlik hizmetlerine yönelik olumlu tutumlarının ise ortalama puanın altında olduğu anlaşılmaktadır. $\mathrm{Bu}$ bulgudan hareketle öğretmenlerin mesleki benlik saygılarının yüksek, psikolojik danışma ve rehberlik hizmetlerine yönelik olumlu tutumlarının ise düşük düzeyde olduğu söylenebilir.

\section{Araştırmanın bağımsız değişkenleri ile psikolojik danışma ve rehberlik hizmetlerine yönelik tutum arasındaki ilişki}

Araştırmanın ikinci problem cümlesi olan "araştırmanın bağımsız değişkenleri (mesleki benlik saygısı, cinsiyet, hizmet yıl1, okulunda psikolojik danışman bulunup bulunmadığ1 ve psikolojik danışma ve rehberlik ile ilgili hizmet içi eğitim alma durumu) ile psikolojik danışma ve rehberlik hizmetlerine yönelik tutum arasındailişki varmıdır?"ın cevaplanmasına yönelik olarak basit korelasyon analizi gerçekleştirilmiştir. Bu analizde cinsiyet, okulunda psikolojik danışman bulunup bulunmadığı ve psikolojik danışma ve rehberlik ile ilgili hizmet içi eğitim alma durumu dummy değişken olarak analize dâhil edilmiştir. Yapılan analizin sonuçları Tablo 4'te sunulmuştur.

Tablo 4.

Araştırmanın Değişkenleri Arasındaki İlişkilerin Belirlenmesine Yönelik Yapılan Basit Korelasyon Analizi

\begin{tabular}{|c|c|c|c|c|c|c|}
\hline & Pdrhyt & Mbs & Cinsiyet & Opdbb & Pdrihead & $\mathrm{Hy}$ \\
\hline Pdrhyt & 1 & $.273^{* *}$ & $.141^{* *}$ & .065 & $.142^{* *}$ & -.085 \\
\hline Mbs & & 1 & $.245^{* *}$ & $-.142^{* *}$ & -.094 & $-.216^{* *}$ \\
\hline Cinsiyet (Kadın) & & & 1 & $-.151^{* *}$ & -.031 & $-.341^{* *}$ \\
\hline Opdbb (Var) & & & & 1 & $.281^{* *}$ & $.124^{*}$ \\
\hline Pdrihead (Evet) & & & & & 1 & $.208^{* *}$ \\
\hline Hy & & & & & & 1 \\
\hline
\end{tabular}

Tablo 4 incelendiğine psikolojik danışma ve rehberlik hizmetlerine yönelik tutum ile mesleki benlik saygısı $(\mathrm{r}=.273, \mathrm{p}<.01)$, cinsiyet $(\mathrm{r}=.141, \mathrm{p}<.01)$ ve psikolojik danışma ve rehberlik ile ilgili hizmet içi eğitim alma durumu $(\mathrm{r}=.142, \mathrm{p}<.01)$ arasında olumlu yönde anlamlı ilişkilerin olduğu görülmektedir. Bununla birlikte psikolojik danışma ve rehberlik hizmetlerine yönelik tutum ile okulunda psikolojik danışman bulunması $(r=.065, \mathrm{p}>.05)$ ve hizmet y1lı $(\mathrm{r}=$ $.085, \mathrm{p}>.05)$ arasında ise anlamlı ilişkilerin olmadığ anlaşılmaktadır. Mesleki benlik saygısı ile cinsiyet $(\mathrm{r}=.245, \mathrm{p}<.01)$, okulunda psikolojik danışman bulunmas1 $(\mathrm{r}=-.142, \mathrm{p}<.01)$ ve hizmet y1lı $(\mathrm{r}=-.216, \mathrm{p}<.01)$ arasında anlamlı ilişkilerin olduğu görülürken, mesleki benlik saygısı ile psikolojik danışma ve rehberlik ile ilgili hizmet içi eğitim alma durumu ( $\mathrm{r}=-.094, \mathrm{p}>.05)$ arasında anlamlı ilişkilerin olmadığı anlaşılmaktadır. Cinsiyet ile okulunda psikolojik danışman bulunması $(\mathrm{r}=-.151, \mathrm{p}<.01)$ ve hizmet y1lı $(\mathrm{r}=-.341, \mathrm{p}<.01)$ arasında olumsuz yönde anlamlı ilişkilere ulaşılırken, cinsiyet ve psikolojik danışma ve rehberlik ile ilgili hizmet içi eğitim alma durumu ( $\mathrm{r}=-.031, \mathrm{p}>.05)$ arasında anlamlı ilişkiler gözlenmemektedir. Okulunda psikolojik danışman bulunması ve psikolojik danışma ve rehberlik ile ilgili hizmet içi eğitim alma durumu $(\mathrm{r}=.281, \mathrm{p}<.01)$ ve hizmet y1lı $(\mathrm{r}=.124, \mathrm{p}<.05)$ arasında olumlu yönde anlamlı ilişkiler görülmektedir. Ayrıca psikolojik danışma ve rehberlik ile ilgili hizmet içi eğitim alma durumu ile hizmet yılının $(\mathrm{r}=.208, \mathrm{p}<.01)$ olumlu yönde anlamlı ilişkili olduğu anlaşılmaktadır. 


\section{Araştırmanın bağımsız değişkenlerinin psikolojik danışma ve rehberlik hizmetlerine yönelik tutumu yordaması}

Araştırmanın üçüncü problem cümlesi olan "araştırmanın bağımsız değişkenleri (mesleki benlik saygısı, cinsiyet ve psikolojik danışma ve rehberlik ile ilgili hizmet içi eğitim alma durumu) psikolojik danışma ve rehberlik hizmetlerine yönelik tutumu yordamaktamıdır?"'n cevaplanmasına ilişkin çoklu doğrusal regresyon analizi gerçekleştirilmiştir. Yapılan analize aşağıda yer verilmiştir.

\section{Çoklu doğrusal regresyon analizi}

Çoklu doğrusal regresyon analizinde cinsiyet ve psikolojik danışma ve rehberlik ile ilgili hizmet içi eğitim alma durumu dummy değişken olarak analize dâhil edilmiştir. Bu analizde, daha önce yapılan basit korelasyon analizinde bağımlı değişken ile arasında anlamlı ilişkilerin olduğu tespit edilen bağımsız değişkenlerin (mesleki benlik saygısı, cinsiyet ve psikolojik danışma ve rehberlik ile ilgili hizmet içi eğitim alma durumu) bağımlı değişkeni (psikolojik danışma ve rehberlik hizmetlerine yönelik tutum) ne şekilde yordadığı belirlenmeye çalışılmıştır. Bu amaçla gerçekleştirilen çoklu doğrusal regresyon analizi sonuçları Tablo 5’te sunulmuştur.

Tablo 5.

Bağımsız Değişkenlerin Psikolojik Danışma ve Rehberlik Hizmetlerine Yönelik Tutumu Yordamasına Yönelik Çoklu Doğrusal Regresyon Analizi

\begin{tabular}{lcccccccccc}
\hline $\begin{array}{l}\text { Bağımsız } \\
\text { değişken }\end{array}$ & $\mathrm{B}$ & $\begin{array}{c}\text { Std. } \\
\text { Hata }\end{array}$ & $\beta$ & $\mathrm{t}$ & $\mathrm{P}$ & $\begin{array}{c}\text { İkili } \\
\mathrm{r}\end{array}$ & $\begin{array}{c}\text { Kismi } \\
\mathrm{r}\end{array}$ & $\mathrm{TV}$ & $\mathrm{VIF}$ & $\begin{array}{c}\text { Durbin } \\
\text { Watson }\end{array}$ \\
\hline Sabit & 10.312 & .577 & & 17.867 & .000 & & & & & \\
MBS & .136 & .024 & .269 & 5.652 & $.000^{* * *}$ & .273 & .265 & .932 & 1.073 & 1.961 \\
Cinsiyet(Kadın) & .273 & .160 & .081 & 1.706 & .089 & .141 & .083 & .940 & 1.064 & \\
Pdrihead(Evet) & .546 & .148 & .170 & 3.678 & $.000^{* * *}$ & .142 & .176 & .991 & 1.009 & \\
\hline
\end{tabular}

$\mathrm{R}=.33 \quad \mathrm{R}^{2}=.11 \quad \mathrm{~F}_{(3-423)=17.194} \mathrm{p}=.000^{* * * *}$

${ }^{* * *} \mathrm{p}<.001$, Mbs: Mesleki benlik saygısı, Pdrihead: Psikolojik danışma ve rehberlik ile ilgili hizmet içi eğitim alma durumu

Tablo 5 incelendiğinde mesleki benlik saygısı, cinsiyet ve psikolojik danışma ve rehberlik ile ilgili hizmet içi eğitim alma durumu değişkenlerinin birlikte psikolojik danışma ve rehberlik hizmetlerine yönelik tutum ile olumlu yönde orta düzeyde anlamlı şekilde ilişkili olduğu ve değinilen değişkenlerin psikolojik danışma ve rehberlik hizmetlerine yönelik tutumun $\%$ 11'ini açıkladığ 1 görülmektedir $\left(\mathrm{R}=.330, \mathrm{~F}_{(3-423)}=17.194, \mathrm{p}<.001\right)$. Standardize edilmiş regresyon katsayısına $[\beta]$ göre bağımsız değişkenlerin psikolojik danışma ve rehberlik hizmetlerine yönelik tutum üzerindeki önem sırasının; mesleki benlik saygısı, psikolojik danışma ve rehberlik ile ilgili hizmet içi eğitim alma ve cinsiyet (kadın) şeklinde olduğu anlaşılmaktadır. Regresyon katsayılarının anlamlılığına ilişkin elde edilen t-testi sonuçları incelendiğinde ise yordayıcı değişkenlerden mesleki benlik saygısı $(\beta=.269, p<.001)$ ve psikolojik danışma ve rehberlik ile ilgili hizmet içi eğitim alma durumu $(\beta=.170, \mathrm{p}<.001)$ değişkenlerinin psikolojik danışma ve rehberlik hizmetlerine yönelik tutumu anlamlı şekilde açıkladığı görülmektedir. Cinsiyetin ise anlamlı bir yordayıcı olmadığı anlaşılmaktadır ( $\beta=.081$, $\mathrm{p}<.05)$.

\section{Tartışma, Sonuç ve Öneriler}

Araştırma kapsamında öncelikle öğretmenlerin mesleki benlik saygılarının ve psikolojik danışma ve rehberlik hizmetlerine yönelik tutumlarının ne düzeyde olduğu belirlenmiştir. Bununla birlikte araştırmanın bağımsız değişkenleri (mesleki benlik saygısı, cinsiyet, hizmet yılı, okulunda psikolojik danışman bulunup bulunmadığı ve psikolojik danışma ve rehberlik ile ilgili hizmet içi eğitim alma durumu) ile öğretmenlerin psikolojik danışma ve rehberlik hizmetlerine yönelik tutumları arasındaki ilişki incelenmiştir. Ayrıca mesleki benlik saygısı, cinsiyet ve psikolojik danışma ve rehberlik ile ilgili hizmet içi eğitim alma durumu 
değişkenlerinin psikolojik danışma ve rehberlik hizmetlerine yönelik tutumu yordayıp yordamadığı belirlenmeye çalışılmıştır. $\mathrm{Bu}$ amaçlar doğrultusunda yapılan analizlere ilişkin sonuçlar ilgili literatürkapsamında tartışılmış, yorumlanmış ve aşağı da sunulmuştur.

Araştırmada elde edilen sonuçlar incelendiğinde öğretmenlerin mesleki benlik saygılarının yüksek düzeyde olduğu bulunmuştur. Elde edilen bu sonuç ile benzer şekilde Irmak'ın (2015) yaptığı araştırmada öğretmenlerin mesleki benlik saygılarının yüksek düzeyde olduğu sonucuna ulaşılmıştır. Araştırmadan elde edilen bu sonuç arzu edilen bir durum olması yönüyle önemlidir.Günümüzde eğitiminnitelikli olması gerektiği görüşünün,ne derece önemliolduğu herkesçe kabul gören bir gerçektir. Eğitim sistemleri ya da yaklaşımları değişiklik göstersede öğretmenlerin eğitimin niteliği üzerindeki etkisi de güncelliğini korumaktadır. Bu araştırmada ulaşılan, öğretmenlerin mesleki benlik saygılarının yüksek oluşu sonucununöğretmenlerin sahip oldukları önem ve sorumluluğun farkında olmaları ile ilgili olduğu düşünülmektedir. Her ne kadar öğretmenlerin istihdamında çeşitli sorunlar yaşanıyor olsada mesleklerine duydukları saygının bu süreçlerden bağımsız olarak korunduğu anlaşılmaktadır.

Araştırmada elde edilen diğer bir sonuç öğretmenlerin psikolojik danışma ve rehberlik hizmetlerine yönelik olumlu tutumlarının düşük düzeyde olduğudur. Bu sonuca göre ögretmenler psikolojik danışma ve rehberlik hizmetleri konusunda olumlu bir anlayış geliştirmemektedirler. Bilindiği üzere öğretmenler eğitim fakültesinden "Rehberlik" isminde bir dersten başarılı olarak mezun olmaktadırlar. Elde edilen sonuca göre yürütülen bu ders, öğretmenlerin psikolojik danışma ve rehberlik hizmetlerini doğru şekilde tanımaları için yeterli olmamış olabilir. Bu noktada eğitim fakültelerinin sorumluluğunun olduğu düşünülmektedir. Öte yandan öğretmenlerinpsikolojik danışma ve rehberlik hizmetleriyle ilgili algıları görev yaptıkları süreç içerisinde olumsuz yönde değişmiş olabilir. Bu durumda ise mesleklerini doğru şekilde tanıtamayan psikolojik danışmanların sorumluluğunun olduğu düşünülmektedir. Ancak gerek eğitim fakülteleri gerekse psikolojik danışmanların psikolojik danışma ve rehberlik hizmetlerini doğru şekilde tanıtamamaları öğretmenlerin bu hizmetlere yönelik olumsuz tutum geliştirmeleri için yeterli bir mazeret olmayacaktır. Psikolojik danışma ve rehberlik hizmetlerinin eğitim ve öğretim süreçlerindeki önem ve gerekliliğinin bilinmesi her öğretmenin öncelikle kendi sorumluluğunda olan bir durumdur. Bu yönüyle öğretmenlerin psikolojik danışma ve rehberlik hizmetlerine yönelik olumlu tutuma sahip olmamalarının kaynağı bu konudaki bilgi eksiklikleri olabilir. Bu konuda yapılan çeşitli araştırmalarda öğretmenlerin psikolojik danışma ve rehberlik hizmetlerine yönelik olumlu bir algıya sahip oldukları görülmüştür (Akgün, 2010; Cooper ve diğerleri, 2005; Gündüz ve diğerleri, 2014; Loynd, Cooper ve Hough, 2005; Owino ve Odera, 2014a; 2014b; Pershing ve Demetropoulos, 1981).Bazı araştırmalarda ise öğretmenlerin rehberlik hizmetlerine ilişkin görüşlerinin olumlu yönde olmadığı sonucuna ulaşılmıştır (Karataş ve Şahin Baltacı, 2013; Mandera, 2013; McPhee, 1985; Moeti, 2016). Dolayısıyla bu araştırmadan elde edilen sonuç ile örtüşen ve çelişen çeşitli araştırma sonuçlarının olduğu anlaşılmaktadır. Psikolojik danışma ve rehberlik hizmetleri bireyin tüm yönleriyle gelişimini amaçlayan çağdaş eğitimin önemli bir öğesidir. Öğretmenler ise bu öğenin olmazsa olmazıdır. Bu durumda okul rehberliğinde önemli fonksiyonları olan öğretmenlerin, bu görevlerini yerine getirebilmeleri için Demir ve Can'ın (2015) de değindiği gibi rehberliğe yönelik doğru bir anlayışa ve olumlu tutuma sahip olmaları gerekmektedir. Dolayısıyla araştırmadan elde edilen bu sonuç psikolojik danışma ve rehberlik hizmetlerinin etkililiği açısından istenmeyen bir durum olarak yorumlanabilir.

Araştırmada öğretmenlerin mesleki benlik saygıları ile psikolojik danışma ve rehberlik hizmetlerine yönelik olumlu tutumları arasında olumlu yönde anlamlı bir ilişki olduğu ortaya çıkmıştır. Dolayısıyla bir öğretmenin mesleğine duyduğu saygı ile psikolojik danışma ve rehberlik hizmetlerine yönelik olumlu tutumu arasında doğrusal bir ilişkinin olduğu anlaşılmaktadır. $\mathrm{Bu}$ sonuca dayalı olarak bir öğretmenin psikolojik danışma ve rehberlik hizmetlerine yönelik tutumunun mesleğine olan saygısından bağımsız düşünülemeyeceği söylenebilir. Öğretmenlik mesleğinin gereklerine inanan bir öğretmen, mesleğine karşı olumlu duygu ve düşünceler beslemektedir. Bu özelliklerin tümü mesleki benlik saygısı kapsamında ele 
alınmaktadır. Bir öğretmenin mesleğinin gereklerini benimsemiş olması, onun mesleğine ve süreçte yer alan diğer faaliyetlere karşı olumlu tutum geliştirdiğinin göstergesidir. Bu kapsamda mesleki benlik saygısı olumlu yönde gelişen bir öğretmenin, psikolojik danışma ve rehberlik hizmetlerine yönelik tutumu da pozitif yönde değişim göstermektedir. Psikolojik danışma ve rehberlik hizmetleri eğitim sürecinin merkezi sinir sistemi gibidir. Bu kapsamda psikolojinin oldukça önemli bir uygulamalı alanıdır (Panja ve Krishna De, 2015). Yadsınamaz bir gerçek olarak psikolojik danışma ve rehberlik hizmetleri okullarda en önemli süreç ve faktörlerden biridir. Eğitim sürecinde bilişsel ve akademik yönden gelişen bireyler yetiştirmekle beraber duygusal yönden de sağlıklı bireylerin gelişimi oldukça önemlidir. $\mathrm{Bu}$ oluşum sürecinde öğretmenlere önemli görev ve sorumluluklar düşmektedir. Bu bağlamda öğretmenlerin öğretim süreçlerine ilişkin algıları ile rehberlik hizmetlerine yönelik anlayışlarının beraber değerlendirilebileceği söylenebilir. Nitekim öğretmenlerin mesleklerini başarıyla yerine getirmelerinin onların sadece kendi uzmanlık alanlarında etkili olmaları ile değil psikolojik danışma ve rehberlik hizmetlerine yönelik faaliyetlerde yapacakları verimli çalışmalarla da ilişkili olduğu düşünülmektedir.

Araştırmada öğretmenlerin psikolojik danışma ve rehberlik hizmetlerine yönelik olumlu tutumları ve psikolojik danışma ve rehberlikle ilgili hizmet içi eğitim alma durumu arasında düşük düzeyde olumlu yönde anlamlı bir ilişkinin olduğu bulunmuştur. Araştırmadan elde edilen bu sonuca göre öğretmenlerin, psikolojik danışma ve rehberlik hizmetleri konusunda bilgi düzeyleri yükseldikçe tutumlarının da olumlu yönde geliştiği anlaşılmaktadır. Kağıtçıbaşı ve Cemalcılar'a (2015) göre tutumun düşünce, duygu ve davranış olmak üzere üçü öğesi bulunmaktadır. Bu üç öğenin uyumlu olmasının o tutumun güçlü olduğu anlamına geldiği vurgulanmıştır. Dolayısıyla bireyin bir konuda olumlu yada olumsuz yöndeki düşüncesinin davranışlarını da etkileyeceği anlaşılmaktadır. Bu bağlamda öğretmenlerin psikolojik danışma ve rehberlik hizmetleri hakkında aldıkları eğitimlerin katkısıyla bilgi eksikliklerinin giderilmesinin, bu hizmetlere yönelik düşüncelerini ve sonuçta tutumlarını etkileyebildiği söylenebilir. Bu düşünceyi destekler nitelikte Kızıl (2007) tarafından yapılan bir araştırmada öğretmenlerin psikolojik danışma ve rehberlik hizmetleri hakkında bilgi eksikliklerinin olduğu ve psikolojik danışmanlarla işbirliğinde sorun yaşadıkları ve yapılan çalışmaların amacına ulaşmadığ yönünde görüş bildirdikleri sonuçlarına ulaşılmıştır. Dolayısıyla öğretmenlerin bilgi eksikliklerinin yapacakları çalışmaların etkililiği ile ilişkili olduğu anlaşılmaktadır. Bu konuda Abbasoğlu (2014), Demir ve Can (2015), Onur (1997) ve Teker (2007) tarafindan yapılan araştırmalarda ise öğretmenlerin psikolojik danışma ve rehberlik ile ilgili hizmet içi eğitimlere katılmaları durumunda psikolojik danışma ve rehberlik hizmetlerine ilişkin tutumlarının olumlu yönde değiştiği sonucuna ulaşılmıştır. Bu sonuçların araştırmadan elde edilen sonuçlarla örtüştüğü görülmektedir. Buna karşın Masibi (1995) tarafından gerçekleştirilen araştırmalarda öğretmenlerin psikolojik danışma ve rehberlik hizmetlerine yönelik hizmet içi eğitim alıp almamaları ile psikolojik danışma ve rehberlik hizmetlerine yönelik tutumları arasında herhangi bir farklılık görülmediğine dair sonuçlara ulaşılmıştır. Araştırmadan elde edilen bu sonuca göre öğretmenlere yönelik uygulanan psikolojik danışma ve rehberlik ile ilgili hizmet içi eğitimlerin yetersiz kaldığı ve rehberlikle ilgili düşünce ve uygulamalarda istenen düzeyde katk1 sağlamadığı söylenebilir. Bu konuda yapılacak olan hizmet içi eğitimlerin içeriğinin zenginleştirilmesi hem öğretmenler hem de öğrenciler açısından önem taşımaktadır. Dolayısıyla psikolojik danışma ve rehberlik hizmetleri ile ilgili yapılacak hizmet içi eğitimlerin nicelik yönünden arttırılmasının yanında nitelik olarak da iyileştirilmesinin bir gereksinim olduğu düşünülmektedir.

Araştırmada kadın öğretmenlerin psikolojik danışma ve rehberlik hizmetlerine yönelik olumlu tutumlarının erkeklere göre daha yüksek olduğu anlaşılmıştır. Ulaşılan bu sonuç psikolojik yardım arama davranışına yönelik tutum kapsamında açıklanabilir. Yapılan araştırmalarda kadınların psikolojik yardım arama davranışına yönelik tutumlarının erkeklerden olumlu yönde daha yüksek olduğu sonuçlarına ulaşılmıştır (Ang, Lim ve Tan, 2004; Erkan, Özbay, Cihangir-Çankaya ve Terzi, 2012; Özbay, Terzi, Erkan ve Cihangir-Çankaya, 2011; Leong ve Zachar, 1999). Kadınların erkeklere göre psikolojik danışma ve rehberlik hizmetlerine 
yönelik tutumlarının daha olumlu olması da bu kapsamda değerlendirilebilir.Araştırmada ulaşılan bu sonuç, Demir ve Can (2015) ve Teker (2007) tarafindan yapılan çalışmaların sonuçları ile paralellik göstermektedir. Ayrıca Stewart (1961) ve Deniz (1993) tarafindan yapılan araştırmalarda kadın öğretmenlerin psikolojik danışma ve rehberlik hizmetlerinden beklentilerinin daha fazla olduğu ileri sürülmüsștür. Buna ek olarak rehberliğe yönelik tutumun erkek öğretmenlerde daha yüksek olduğunu gösteren araştırmaların (McPhee, 1985) da olması cinsiyetin rehberliğe yönelik tutum üzerindeki etkisinin tutarsız olduğunu göstermektedir. Bir takım araştırmalarda ise öğretmenlerin psikolojik danışma ve rehberlik hizmetleri ile ilgili görüşlerinin cinsiyetleri açısından farklılık göstermediği bulunmuştur (Gündüz ve diğerleri, 2014; Onur, 1997; Öztürk, 1999; Yumrutaş, 2006). Öğretmenlerin psikolojik danışma ve rehberlik hizmetlerine yönelik tutumunun bazı çalışmalarda cinsiyetlerine göre anlamlı farklılık göstermesi bazılarındaise göstermemesinin temel sebebi cinsiyet dışındaki başka değişkenlere dayandırılabilir. Nitekim tutumlar birçok değişkenin etkisi altında kalabilir. Bu nedenle farklı sonuçların elde edildiği çalışmalarda öğretmenlerin psikolojik danışma ve rehberlik hizmetlerine yönelik tutumlarını çalışılan kurumun iklimi ve kültürü, kurumdaki iş yükü ve okul yönetiminin psikolojik danışma ve rehberlik hizmetlerine yönelik bakışı gibi çeşitli faktörlerin etkileyebileceği düşünülmektedir.

Araştırmada öğretmenlerin psikolojik danı̧̧ma ve rehberlik hizmetlerine yönelik tutumları ile okulunda psikolojik danışman bulunması arasında anlamlı bir ilişkinin olmadığı bulunmuştur. $\mathrm{Bu}$ sonuca göre okullarda psikolojik danışman bulunup bulunmamasının öğretmenlerin psikolojik danışma ve rehberlik hizmetleri ile ilgili görüşleri üzerinde herhangi bir etkisinin olmadığı anlaşılmaktadır. Dolayısıyla durumun okulda psikolojik danışmanın varlığı ile ilgili değil yürütülen faaliyetlerin niteliğgi ile ilgili olduğu söylenebilir. Bu bağlamda psikolojik danışma hizmetleri üzerinde psikolojik danışman yetersizliğinin dışında çeşitli faktörlerin etkili olduğu düşünülmektedir. Pişkin (2006) psikolojik danışma hizmetlerinin niteliğini olumsuz yönde etkileyen bu faktörleri; "Türk kültürüne özgü model arayışı, alan dış1 atamalar sorunu, fizikî koşullar, ölçme araçları ve bilişim teknolojilerine ilişkin yetersizlikler ile PDR lisans programlarından mezun olanların yetişme eksikliklerinin olması" ş̧eklinde ifade etmiştir. Değinilen bu problemlerin okulda psikolojik danışman bulunsa dahi yapılan çalışmaların niteliğini olumsuz yönde etkilediği söylenebilir. Dolayısıyla bu problemlerin çözümünün önem arz ettiği söylenebilir.Değinilen bu ve benzeri durumlar öğretmenlerin psikolojik danışma ve rehberlik hizmetlerine yönelik tutumları üzerinde etkili olmuş olabilir. İlgili literatür incelendiğinde Abbasoğlu (2014) araştırmasında, okuldaki rehber öğretmen sayısı ile öğretmenlerin rehberlik faaliyetlerine yönelik tutumu arasında anlamlı bir farklılık bulunmadığını ortaya koymuştur. Benzer şekilde Gündüz ve diğerleri (2014) de yaptıkları çalışmada öğretmenlerin psikolojik danışma ve rehberlik hizmetlerine ilişkin tutumlarının okulda çalışan psikolojik danışman sayısına göre farklılık göstermediği sonucuna ulaşmıştır. Bu araştırmada elde edilen diğer bir sonuca göre okullarda psikolojik danışman eksiği halen gözle görülür biçimde devam etmektedir. Okullarda psikolojik danışman bulunmaması veya sayısının yetersiz olması psikolojik danışma ve rehberlik hizmetlerinin öğrencilere yeterince tanıtılamadığını veya sunulamadığını düşündürmektedir. Dolayısıyla psikolojik danışma ve rehberlik hizmetlerinin uygulanması ile ilgili bir takım eksikliklerin devam ettiği anlaşılmaktadır. Büyükkaragöz'ün (1988) ifade ettiğine göre, öğretmenler psikolojik danışma ve rehberlik hizmetlerinin başarılı olması için okulda en az bir rehber öğretmenin bulunması gerektiğine inanmaktadırlar. Bu sonuca benzer şekilde Karataş ve Şahin Baltacı (2013) ile Taşkaya ve Kurt (2010) öğretmenlerin psikolojik danışman sayısının yetersiz olduğuna değindiklerini ifade etmişlerdir. Bu bağlamda okullarda eksikliği sürmesinden dolayı bu talebi karşılayabilmek amacıyla yeterli sayıda psikolojik danışman ihtiyacını sağlayacak programların yapılandırılmasının gerekli olduğu görülmektedir. Ancak araştırmada ortaya çıkan sonuçtan hareketle durumun nicelik değil nitelik yönünden zenginleştirilmesinin daha önemli olduğu anlaşılmaktadır. Dolayısıyla psikolojik danışmanın okulda var olmasından daha önemli olan durum, psikolojik danışmanların bulundukları okullarda varlıklarını hissettirmelerinin gerekliliğidir. Bu kapsamda psikolojik danışmanların yürüttükleri çalışmaların niteliklerinin 
arttırılmasının, öğretmenlerin psikolojik danışma ve rehberlik hizmetlerine yönelik olumlu tutum geliştirmelerine katkı sağlayacağı düşünülmektedir.

Araştırmada öğretmenlerin psikolojik danışma ve rehberlik hizmetlerine yönelik tutumları ile hizmet yılları arasında anlamlı bir ilişkinin olmadığı bulunmuştur. Bir başka deyişle öğretmenlerin hizmet sürelerine göre psikolojik danışma ve rehberlik hizmetlerine yönelik tutumları farklılaşmamaktadır. Bu sonuçlara benzer şekilde Demir ve Can (2015), Öztürk (1999), Stewart (1961) ve Teker (2007) tarafından yapılan araştırmalarda öğretmenlerin psikolojik danışma ve rehberlik hizmetlerine yönelik tutumları ile hizmet yılları arasında anlamlı ilişki bulunmamıştır. Bu araştırmaların aksine Abbasoğlu (2014), McPhee (1985) ve Pershing ve Demetropoulos (1981) çalışmalarında deneyimleri az olan öğretmenlerin rehberliğe yönelik daha olumlu tutumlara sahip olduklarını ortaya koymuşlardır. Değinilen araştırma sonuçlarına göre psikolojik danışma ve rehberlik faaliyetlerine yönelik tutum ile öğretmenlerin kıdemleri arasındaki ilişkide tutarsızlıklar olduğu görülmektedir. $\mathrm{Bu}$ sonuçlar değerlendirildiğinde, daha az hizmet yılına sahip olan bir öğretmenin rehberlik programını daha fazla zaman ve emek harcayarak uygulaması beklenebilir. Çünkü kıdemli öğretmenlerin alıştığı bir uygulamayı değiştirmesi zorken, yeni öğretmenlerin yeni programlara ve uygulamalara daha kolay adapte olabileceği söylenebilir. $\mathrm{Bu}$ durumda değinilen tutarsızlıkların çalışma gruplarından kaynaklanıyor olabileceği söylenebilir.

Araştırma sonucunda mesleki benlik saygısı, cinsiyet ve psikolojik danışma ve rehberlik ile ilgili hizmet içi eğitim alma durumu değişkenlerinin birlikte psikolojik danışma ve rehberlik hizmetlerine yönelik olumlu tutum ile orta düzeyde olumlu yönde anlamlı şekilde ilişkili olduğu ve değinilen değişkenlerin psikolojik danışma ve rehberlik hizmetlerine yönelik tutumun \%11'ini açıkladığı belirlenmiştir. Farklı bir ifadeyle öğretmenlerin psikolojik danışma ve rehberlik hizmetlerine yönelik tutumunun \%88'inin bu değişkenlerin dışındaki faktörlerin etkisi altında olduğu anlaşılmaktadır. Bu sonuca göre değinilen yordayıcı değişkenlerin yordanan değişken üzerindeki etkisinin anlamlı ancak düşük düzeyde olduğu anlaşılmaktadır.Bununla birlikte yordayıcı değişkenlerden sadece mesleki benlik saygısı ve psikolojik danışma ve rehberlik ile ilgili hizmet içi eğitim alma durumu değişkenlerinin psikolojik danışma ve rehberlik hizmetlerine yönelik tutumu anlamlı şekilde açıkladığı bulunmuştur. Cinsiyetin ise tek başına anlamlı bir yordayıcı olmadığı saptanmıştır.Elde edilen bu sonuçların tutumun doğası ile ilgili olduğu düşünülmektedir.Tutumun düşünce, duygu ve davranış olmak üzere üç boyutunun olduğu ve çeşitli psiko-sosyal değişkenlerin etkisine açı olduğu göz önünde bulundurulduğunda tutumu etkileyen değişkenlerin açık bir şekilde belirlenmesi zor olabilmektedir.Bu konuda Demir ve Can (2015) tarafindan yapılan bir araştırmada kadınların psikolojik danışma ve rehberliğe yönelik tutumlarının erkeklerden daha olumlu olduğu ancak cinsiyete dayalı bu farklılığın etki büyüklüğünün oldukça düşük olduğu sonucuna ulaşılmıştır. Benzer şekilde psikolojik danışma ve rehberlik hizmetleri ile ilgili hizmet içi eğitime katılmış olan öğretmenlerin psikolojik danışma ve rehberliğe yönelik tutumlarının katılmayanlara göre daha olumlu olduğu ancak hizmet içi eğitime katılmış olmaya dayalı bu farklılığın etki büyüklüğün yüksek düzeyde olmadığı ortaya konulmuştur.Değinilen sonuçlar ile bu araştırmanın sonuçlarının benzerlik gösterdiği anlaşılmaktadır.Bu araştırmada ayrıca mesleki benlik saygısının, psikolojik danışma ve rehberlik hizmetlerine yönelik olumlu tutum üzerindeki etkisinin, psikolojik danışma ve rehberlik ile ilgili hizmet içi eğitim alma durumuna göre daha fazla olduğu sonucuna ulaşılmıştır. Bu sonuç göstermektedir ki öğretmenlerin psikolojik danışma ve rehberlik hizmetlerine yönelik tutumları, dışsal bir süreç olan psikolojik danışma ve rehberlik ile ilgili hizmet içi eğitim alma durumundan daha çok içsel bir süreç olan mesleki benlik saygısı ile ilgilidir. Öğretmenlerin faaliyet alanları her ne kadar kanunlar ve yönetmeliklerle belirlenmiş olsave onlara eğitim ve teknik destekler sunuluyor olsa da öğretmenlerin yaptıkları işe yönelik geliştirdiği saygının bahsedilen değişkenlerden daha etkili olduğu anlaşılmaktadır. Dolayısıyla bir öğretmenin kendi mesleğine saygı duyması bir anlamda psikolojik danışma ve rehberlik hizmetlerine duyduğu saygı ile doğrudan ilişkilidir.Bir konuda eğitim almasının kişinin tutumu üzerinde etkili olduğu ancak yaptığı işe duyduğu saygının daha güçlü bir belirleyici olduğu anlaşılmaktadır. 
$\mathrm{Bu}$ araştırma sonucunda öğretmenlerin psikolojik danışma ve rehberlik hizmetlerine yönelik olumlu tutumları ve psikolojik danışma ve rehberlikle ilgili hizmet içi eğitim alma durumu arasında düşük düzeyde olumlu yönde anlamlı bir ilişkinin olduğu sonucuna ulaşılmıştır. $\mathrm{Bu}$ ilişkinin neden düşük düzeyde olduğunun belirlenmesine yönelik olarak, yapılan hizmet içi eğitim faaliyetleri incelenebilir ve gerekli görülmesi halinde eğitimlerin içeriğinde düzenlemelere gidilebilir. Araştırmanın diğer bir sonucukadın öğretmenlerin tutumlarının erkeklere göre daha olumlu olduğudur. Diğer sonuçlarda ise öğretmenlerin psikolojik danışma ve rehberlik hizmetlerine yönelik tutumları ile okulunda psikolojik danışman bulunması ve hizmet yılları arasında anlamlı ilişkinin olmadığı belirlenmiştir. Bu değişkenlerin etkisinin daha ayrıntılı şekilde ortaya konulması amacıyla görüşmeye dayalı farklı araştırmalar yapılabilir. Bu araştırma yalnızca öğretmenlerle gerçekleştirilmiştir. Bu durum, çalışmanın bir sınırlılığıdır. İleride yapılacak araştırmalarda yöneticiler ve psikolojik danışmanların da görüşleri incelenebilir. Araştırmanın diğer bir sınırlılığı öğretmenlerin psikolojik danışma ve rehberlik hizmetlerine yönelik tutumlarının yordanmasında sadece mesleki benlik saygısı, cinsiyet, hizmet yılı, okulunda psikolojik danışman bulunup bulunmadığı, psikolojik danışma ve rehberlik ile ilgili hizmet içi eğitim alma durumu değişkenleri dikkate alınmıştır. Farklı bir araştırmada psikolojik danışma ve rehberlik hizmetlerine yönelik tutum değişkenini yordayabileceği düşünülen çeşitli değiş̧kenler (mesleki özyeterlik algısı, tükenmişlik, mesleki doyum, görev yapılan kurum türü (kamu-özel)) işe koşularak daha kapsamlı sonuçlara ulaşılabilir. Bununla birlikte bu araştırmada yalnızca nicel araştırma yaklaşımı tercih edilmiştir. Nicel ve nitel yaklaşımların birlikte ele alındığı karma yaklaşım temelli çalışmalar yapılarak elde edilen sonuçların genellenebilirliği arttırılabilir. Bu konuda yapılacak çalışmaların, farklı şehirlerde yer alan çeşitli kademelerdeki okulları kapsayan daha geniş ve değişik örneklem grupları üzerinde gerçekleştirilmesinin de literatüre önemli düzeyde katkı sağlayacağı düşünülmektedir.Ayrıca bu araştırmadan elde edilen sonuçlar öğretmen yada öğretmen adaylarının eğitimlerinde kullanılarak katılımcılara psikolojik danışma ve rehberlik hizmetlerine yönelik tutum ile ilgili farkındalıklar yaşatılabilir.

\section{Kaynaklar}

Abbasoğlu, B. (2014). Illkokul ve ortaokul ögretmenlerinin rehberlik ve psikolojik danışma faaliyetlerine yönelik tutumlarının incelenmesi (Yalova ili örneği) (Yayımlanmamış yüksek lisans tezi). Yeditepe Üniversitesi, İstanbul.

Abbasoğlu, E. ve Öncü, E. (2013).Beden eğitimi öğretmeni adaylarının benlik saygıları ve öğretmenlik mesleğine yönelik tutumları. Ahi Evran Üniversitesi Kırşehir Eğitim Fakültesi Dergisi, 14(2),407-425.

Akgün, E. (2010). Okul öncesi öğretmenlerinin bakış açısıyla anasınıflarındaki rehberlik hizmetlerinin değerlendirilmesi, İlkögrretim Online, 9(2), 474-483.

Ang, R. P., Lim, K. M. veTan, A. (2004). Effects of gender and sex role orientation on helpseeking attitudes.Current Psychology, Developmental, Learning, Social, 23(3), 203214.

Arıcak, T. (1999a). Öğretmen adaylarının benlik saygısı ve mesleki benlik saygılarının geliştirilmesine yönelik bir grupla psikolojik danışma uygulaması. M. Ü. Atatürk Eğitim Fakültesi Ĕgitim Bilimleri Dergisi, 11, 11-22.

Arıcak, T. (1999b). Grupla psikolojik danışma yoluyla benlik saygısının geliştirilmesi (Yayımlanmamış doktora tezi). Marmara Üniversitesi, İstanbul.

Atıcı, M., Özyürek, R. ve Çam, S. (2005).Okul danışmanlığı uygulamalarının yetkinlik beklentisi algıları ve mesleki benlik saygisı üzerindeki etkilerinin boylamsal olarak incelenmesi.Türk Psikolojik Danışma ve Rehberlik Dergisi, 3(24), 7-23.

Baloğlu, N., Karadağ, E., Çalışkan, N. ve Korkmaz, T. (2006). İlköğretim öğretmenlerinin mesleki benlik saygısı ve iş doyumları arasındaki ilişkinin değerlendirilmesi. Ahi Evran Üniversitesi Kirşehir Ë̆itim Fakültesi Dergisi, 7(2), 345-358. 
Baumeister, R. F.,Campbell, J. D., Krueger, J. I.VeVohs, K. D. (2003). Does high self-esteem cause better performance interpersonal success happiness or healthier life styles? Psychological Science in the Public Interest, 4(1), 1-44.

Biroğul, H., K. ve Deniz, M., E. (2015). Farklı branş öğretmenlerinin akademik iyimserlikleri ile mesleki benlik saygıları arasındaki ilişkinin incelenmesi. VII. Ulusal Lisansüstü Ĕ̈itim Sempozyumu Bildiriler Kitabı içinde (s. 48-53).

Bozali, S. ve Camadan, F. (2018). Okul öncesi öğretmenlerinin mesleki haz düzeylerinin açıklanmasında mesleki benlik saygısı ve rol fazlası davranışların rolü.Başkent University Journal of Education, 5(1), 28-40.

Bülbül, Ö. (2009). İlköğretim okullarında görev yapan ögretmelerin rehberlik görevleriyle ilgili tutum ve davranışlarının incelenmesi (Yayımlanmamış yüksek lisans tezi). Kahramanmaraş Sütçü İmam Üniversitesi, Kahramanmaraş.

Büyükkaragöz, S. (1988). Orta dereceli okullarda rehberlik ve eğitsel kollarla ilgili programın uygulanmas1. S. Ü Ĕ̈itim Fakültesi Dergisi, 2, 16-28.

Büyüköztürk, Ş. (2009). Sosyal bilimler için veri analizi. Ankara: Pegem Akademi Yayıncılık.

Büyüköztürk, Ş., Kılıç-Çakmak, E., Akgün, Ö. E., Karadeniz, Ş. ve Demirel, F. (2014). Bilimsel araştırma yöntemleri. Ankara: Pegem Akademi Yayıncılık.

Can, A. (2013). Spss ile bilimsel araştırma sürecinde nicel veri analizi. Ankara: Pegem Akademi Yayıncilik.

Cooper, M. Hough, M. ve Loynd, C. (2005). Scottish secondary school teachers' attitudes towards, and conceptualisations of, counselling. British Journal of Guidance and Counselling, 33(2), 199-211.

Çam, S. (2004). Okullarda rehberlik hizmet alanları-birimleri. G. Can (Yay.haz.). Psikolojik danışma ve rehberlikiçinde (s. 47-72). Ankara: Pegem Akademi Yayıncılık.

Çelikten, M.,Şanal, M. ve Yeni, Y. (2005). Öğretmenlik mesleği özellikleri. Sosyal Bilimler Enstitüsü Dergisi, 19(2), 207-237.

Demir, M. ve Can, G. (2015). Sınıf rehber öğretmenlerinin psikolojik danışma ve rehberlik anlayışları ile psikolojik danışma ve rehberliğe yönelik tutumları.Eğitim ve Bilim, 40(179), 307-322.

Deniz, Z. (1993). Liselerdeki yönetici, sinıf öğretmeni ve ders öğretmenlerinin psikolojik danışma ve rehberlik hizmetlerine ilişkin beklentilerinin bazı değişkenlere göre incelenmesi (Yayımlanmamış yüksek lisans tezi). İnönü Üniversitesi, Malatya.

Dilmaç, B. ve Ekşi, H. (2012).Ögrretmenlerin sahip oldukları değerlerin ve özgeci davranışlarının mesleki benlik saygısı açısından incelenmesi.Değerler Ĕ̈itimi Dergisi, $10(23), 65-82$.

Dursun, Ö. Ö.,Çuhadar, C. ve Tanyeri, T. (2014). Bilişim teknolojileri öğretmen adaylarının mesleki benlik saygıları. Pamukkale Üniversitesi Eğitim Fakültesi Dergisi, 35, 131142.

Er, A. Ç. (2017). Rehber öğretmenlerde mesleki benlik saygisl, duygusal zeka ve yaşam doyumlarının çeşitli değişkenler açısından incelenmesi (Yayımlanmamış yüksek lisans tezi). Necmettin Erbakan Üniversitesi Eğitim Bilimleri Enstitüsü, Konya.

Erkan, S., Özbay. Y., Cihangir-Çankaya, Z. ve Terzi, Ş. (2012). Üniversite öğrencilerinin yaşadıkları problemler ve psikolojik yardım arama gönüllükleri.Eğitim ve Bilim, 37(164), 94-107.

Field, A. P., Miles, J. veField, Z. (2009). Discovering statistics using R. London: Sage Publication.

Friedman, I. A. ve Farber, B. A. (1992). Professional Self-Concept as a predictor of teacher burnout. The Journal of Educational Research, 86(1), 28-35.

Gazioğlu, E. İ. ve İlgar, Ş. M. (2008). Öğretmen ve öğretmen adayları için rehberlik. Ankara: PegemA Akademi Yayınc1lk.

Glotova, G. ve Wilhelm, A. (2014) Teacher's self-concept and self-esteem in pedagogical communication.Procedia - Social and Behavioral Sciences, 132, 509-514. 
Gündem, F. (2009).Illköğretim okulu öğretmenlerinin motivasyon, mesleki benlik saygısı ve mesleğe yönelik yetkinlik duygusu algıları arasındaki etkileşim (Yayımlanmamış Yüksek Lisans Tezi). Yeditepe Üniversitesi, İstanbul.

Gündüz, B,. İnand1, Y. ve Tunç, B. (2014). Okul yöneticilerinin psikolojik danışma ve rehberlik hizmetlerine ilişkin görüşleri: Betimsel bir çalışma. Eğitim Bilimleri Araştırmaları Dergisi, 4(2),19-34.

Irmak, M. (2015). Illkokul ve ortaokul ögretmenlerinin mesleki benlik saygılarının belirlenmesi(Yayımlanmamış yüksek lisans tezi). İstanbul Sabahattin Zaim Üniversitesi, İstanbul.

Jan, F., Khan, I., Khan, S., Khan, M., N. ve Saif, N. (2015).The factors affecting teachers' selfesteem in the higher educational institutions.Research on Humanities and Social Sciences, 5(9), 132-136.

Kağıtçıbaşı, Ç. ve Cemalcılar, Z. (2015).Insan ve insanlar, (17.Bask1). İstanbul: Evrim Yayıncilik.

Kalayc1, Ş. (2009). Spss uygulamalı çok değişkenli istatistik teknikleri. Ankara: Asil Yayınları.

Karataş, Z. ve Şahin Baltacı, H. (2013). Ortaöğretim kurumlarında yürütülen psikolojik danışma ve rehberlik hizmetlerine yönelik okul müdürü, sınıf rehber öğretmeni, öğrenci ve okul rehber öğretmeninin (psikolojik danışman) görüşlerinin incelenmesi. Ahi Evran Üniversitesi Kırşehir Eğitim Fakültesi Dergisi (KEFAD), 14(2), 427-460.

Kepçeoğlu, M. (1987). Eğitimde psikolojik danışma ve rehberlik uygulamalarının gelişimi ve belli başl1 sorunları. Hacettepe Üniversitesi Eğitim Fakültesi Dergisi, 2(2), 264-272.

Kızıl, D. (2007). Ortaöğretim kurumlarındaki rehber ögretmenlerin ve sinıf rehber ögretmenlerin sinıf içi rehberlik etkinlikleri ile ilgili görüşleri (Yayımlanmamış Yüksek Lisans Tezi). Selçuk Üniversitesi, Konya.

Kline, R. B. (2011). Principles and practice of structural equation modeling(3rd ed.). New York: The GuilfordPress.

Kutlu, M. ve Soğukpınar, B. U. E. (2015). Rehber öğretmenlerin benlik saygısı ile mesleki benlik saygısı düzeylerinin çeşitli değişkenler açısından incelenmesi. E-International Journal of Educational Research, 6(1),84-101.

Laurencelle, L. ve Dupuis, F. (2002). Statistical tables explained and applied. Singapore: World Scientific Publishing Co. Pte. Ltd.

Leong, F. T. L. ve Zachar, P. (1999).Gender and opinions about mental illness as predictors of attitudes toward seeking professional psychological help.British Journal of Guidance \& Counselling, 27(1), 123-132.

LoVette, O. K. (1997). To achieve school reform education leaders must focus on teacher selfconcept. Education, 118(2), 303-306.

Loynd, C., Cooper, M. ve Hough, M. (2005). Scottish secondary school teachers' attitudes towards, and conceptualisations of counseling. British Journal of Guidance \& Counselling, 33(2), 199-211.

Mandera, M. L. (2013). Perceptions of teachers and students towards guidanceand counselling services in public secondary schools in ongata rongai and ngong zones of kajiado north district, Kajiado County-Kenya(Unpublished Master thesis).The Catholic University of Eastern Africa Nairobi, Kenya.

Masibi, E., H. (1995). Attitudes of black secondary school teachers toward school guidance in the potchefstroomarea, South Africa(Unpublished dissertations). Western Michigan University, Michigan.

McPhee, S. A. (1985). Educators' perceptions and attitudes toward school counselling and student personnel services: A cultural perspective. International Review of Education, 31(1), 19-32.

Millî Eğitim Bakanlığı Rehberlik ve Psikolojik Danışma Hizmetleri Yönetmeliği (2001). Resmî Gazete:17.4.2001/24376, Tebliğler Dergisi: Mayıs 2001/2524. Erişim adresi: http://orgm.meb.gov.tr/alt_sayfalar/mevzuat/Milli\%20E\%C4\%9Fitim\%20Bakanl\%C4 
$\% \mathrm{~B} 1 \% \mathrm{C} 4 \% 9 \mathrm{~F} \% \mathrm{C} 4 \% \mathrm{~B} 1 \% 20$ Rehberlik\%20ve\%20Psikolojik\%20Hizmetler\%20Y\%C3 $\%$ B6netmeli\%C4\%9Fi.htm

Moeti, B. (2016). Perceptions of teacher counsellors on assessment of guidance and counselling in secondary schools.International Journal of Learning, Teaching and Educational Research, 15(6), 145-155.

Onur, M. (1997). Giresun ili merkez liselerindeki yönetici, öğretmen ve ögrencilerin rehberlik anlayışlarının incelenmesi (Yayımlanmamış yüksek lisans tezi).Karadeniz Teknik Üniversitesi, Trabzon.

Owino, J.ve Odera, F. Y. (2014a). Attitude of Head Teachers towards Guidance and Counseling in Primary Schools in Kisumu West Sub County.International Journal of Humanities and Social Science Invention, 3(7), 55-62.

Owino, J.ve Odera, F. Y. (2014b). Constraints affecting attitude of teachers towards practicing guidance and counselling in primary schools in Kisumu West Sub County. European Journal of Research and Reflection in Educational Sciences, 2(3), 34-47.

Özbay.Y., Terzi, Ş., Erkan, S. ve Cihangir-Çankaya, Z. (2011).Üniversite öğrencilerinin profesyonel yardım arama tutumları, cinsiyet rolleri ve kendini saklama düzeyleri.Pegem Ĕ̈itim ve Öğretim Dergisi, 1(4).59-71.

Özbek, R., Kahyaoğlu, M. ve Özgen, N. (2007). Öğretmen adaylarının öğretmenlik mesleğine yönelik görüşlerinin değerlendirilmesi. Sosyal Bilimler Dergisi, 9(2), 221-232.

Özoğlu, S. Ç. (1977). Eğitimde güncel bir konu: Okullarda rehberlik hizmetleri. Eğitim ve Bilim, 1(6), 18-27.

Öztürk, A. (1999). Lise öğretmenlerinin rehberlik hizmetlerini algılama düzeyleri (Yayımlanmamış yüksek lisans tezi), Uludağ Üniversitesi, Bursa.

Öztürk, G. (2008). Devlet ilköğretim okullarında görevli öğretmenlerin çalışma koşulları, özyeterlilikleri ve mesleki benlik saygıları arasındaki ilişki (Yayımlanmamış Yüksek Lisans Tezi).Marmara Üniversitesi, İstanbul.

Panja, K. S. ve Krishna De, K. (2015). Attitude towards career guidance and counselling among higher secondary school teachers under presents cenario in West Bengal. Indian Journal of Applied Research, 5(12), 357-362.

Pehlivan, H. (1993). Öğretmen yetiştirmeye hizmet bakımından Anadolu öğretmen lisesi uygulamasına genel bir bakış. Hacettepe Üniversitesi Ĕ̈itim Fakültesi Dergisi, 9, 237-248

Pershing, J. A. ve Demetropoulos, E. G. (1981). Guidance and guidance systems in secondary schools: The teacher's views. The Personel and Guidance Journal, 59(7), 455-459.

Pişkin, M. (2006). Psikolojik danışma ve rehberliğin dünü, bugünü ve yarını.M. Hesapçioğlu ve A. Durmuş(Ed.) Türkiye'de eğitim bilimleri: Bir bilanço denemesiiçinde. Nobel Yayınları: Ankara.

Roe, J.ve Gray, A. (1991).Teachers' professional self-esteem in the light of occupational stress factors. Australian Association for Research in Education Annual Conference, Surfers Paradise, Gold Coast, 26-30 November, Australia.

Rosenberg, M., Rosenberg, F., Schooler, C. ve Schoenbach, C. (1995). Global self-esteem and specific self-esteem: different concepts, different outcomes. American Sociological Review, 60(1), 141-156.

Sarı, K. (2016).Okul öncesi ögretmenlerinin çocuk sevgilerinin ve mesleki benlik saygllarının profesyonellik değişkenleri açısından incelenmesi (Yayımlanmamış Yüksek Lisans Tezi).Necmettin Erbakan Üniversitesi, Konya.

Sayın, S. (2003). Farklı programlarda okuyan öğretmen adayı üniversite öğrencilerinin empatik eğilimi, öğretmenlik mesleğine karşı tutum ve mesleki benlik saygısı. Burdur Ë̆itim Fakültesi Dergisi, 34(6), 74-84.

Sayın, S. (2005). Öğretmen adaylarının öğretmenlik mesleğine karşı tutumları ve mesleki benlik saygilarının incelenmesi. Eurasian Journal of Educational Research, 19, 272-281.

Stewart, J. A. (1961). Factors influencing teachers' attitudes toward and participation in guidance services. Personnel and Guidance Journal, 36, 729-734. 
Şencan, H. (2005).Sosyal ve davranışsal ölçümlerde güvenilirlik ve geçerlilik. Ankara: Seçkin Yayınevi.

Tabassum, F. ve Ali, A. A. (2012) Professional self-esteem of secondary school teachers, Asian Social Science, 8(2), 206-210.

Taşkaya, S. M. ve Kurt Y. (2010). Ilköğretim okullarında rehberlik ve psikolojik danışma hizmetlerine ilişkin sını ögretmenlerinin görüşleri. International Conference on New Trends in Education and Their Implications. 11-13 November, Antalya.

Teker, A. (2007). Illköğretim I. kademede görev yapan sinlf ögretmenlerinin rehberlik görevleri ile ilgili görüşleri ve uygulamaları (Yayımlanmamış yüksek lisans tezi), Beykent Üniversitesi, İstanbul.

Ünal, E. ve Şimşek, S. (2008). İlköğretim bölümü anabilim dallarında öğrenim gören öğretmen adaylarının mesleki benlik saygılarının çeşitli değişkenler açısından incelenmesi. Ilkögrretim Online, 7(1),41-52.

Yerlikaya, İ., Sak, R. ve Şahin Sak, İ. T. (2014). Okul öncesi eğitimde psikolojik danışma ve rehberlik hizmetleri: okul öncesi öğretmen adaylarının ve psikolojik danışman adaylarının görüşleri. Uşak Üniversitesi Sosyal Bilimler Dergisi, 7(2), 286-299.

Yıldırım, Y.,Kırımoğlu, H. ve Temiz, A. (2010). Beden eğitimi ve spor öğretmenlerinin mesleki benlik saygısı (Hatay İl Örneği). Selçuk Üniversitesi Beden Ĕgitimi ve Spor Bilim Dergisi, 12(1), 29-35.

Yumrutaş, A. (2006). İlköğretim okullarında görev yapan öğretmenlerin rehberlik görevleriyle ilgili görüs ve uygulamalarının incelenmesi (Yayımlanmamış yüksek lisans tezi). Yeditepe Üniversitesi, İstanbul.

Zoroğlu, Ö. (2014). Okul öncesi ögretmenlerinin mesleğe yönelik tutumları, mesleki benlik saygıları ile iş doyumları arasındaki ilişsk (Yayımlanmış yüksek lisans tezi). Karadeniz Teknik Üniversitesi, Trabzon.

\section{Extended Abstract}

\section{Introduction}

Çelikten, Şanal and Yeni (2005) sort the role of teaching as representation, leadership, teaching, mediation, arbitration and guidance. One of these roles, guidance, entered the Turkish National Education System as a concept in 1950s and gave rise to crucial changes in insight and application (Kepçeoğlu, 1987). Nowadays teachers' guidance role has been carried out within the scope of professional psychological counseling and guidance services. It is evaluated that teachers' views about psychological counseling and guidance service affect the maintaining of these service accurately (Gündüz, İnand $1 \&$ Tunç, 2014). In this context, the attitude of teachers towards the psychological counseling and guidance services is considered as a variable that affects the effectiveness of the activities to be done.

Within the lights of these evaluations above, it is understood that teachers' professional self-esteem and their attitude towards psychological counseling and guidance services are the important variables. The aim of this research is to determine the relationship between teachers' professional self-esteem and their attitude towards the psychological counseling and guidance services.

\section{Method}

In this research, relational screening method which aims to determine the relationships between variables which have been used. In this context, the relationship between teachers' professional self-esteem, gender, the years of service, having or not having psychological counselor in his/ her school, getting in-service training in psychological counseling and guidance and their attitude towards psychological counseling and guidance service was examined.

The study group of the study is composed of 427 (female: 282, male: 145) preschool, primary, secondary and high school teachers working in Rize city center during 2015-2016 academic year. In this research, "Arıcak Professional Self-Esteem Scale" (Arıcak, 1999b) was 
used to determine their professional self-esteem and "Teachers' Attitude Scale Concerning Guidance Service" (Abbasoğlu, 2014) was used to determine their attitude towards psychological counseling and guidance service and "Personal Information Form" was used in order to get some information about demographic features.

During the application of assessment instruments, first of all, permission from the researchers to use the instruments and from the National Education Directorate to apply them was received. Three instruments filled in imperfectly were eliminated from the research because they may affect the results of the research negatively.

\section{Result and Discussion}

It was found that teachers have high professional self-esteem when the results were taken into consideration. The results of Irmak's research (2015) coincide with this result. The result obtained from the research is important as it is a desired case.

Another result obtained from the research is that teachers' positive attitude towards psychological counseling and guidance service is low. Some research shows that teachers have a positive perception (Akgün, 2010; Cooper, Hough \& Loynd, 2005; Gündüz, et al., 2014; Loynd, Cooper \& Hough, 2005; Owino \& Odera, 2014a; 2014b; Pershing \& Demetropoulos, 1981), but it has been inferred from the research by Karataş and ŞahinBaltacı (2013), Mandera (2013), McPhee (1985) and Moeti (2016) that teachers' attitude towards psychological counseling and guidance is not positive. This result obtained from the research can be interpreted as an undesired situation.

In the research, it is clear that there is a positive and meaningful relationship between teachers' professional self-esteem and their attitude towards psychological counseling and guidance service. In other words, it is seen that as the teachers' professional self-esteem increases, their positive attitude towards the psychological counseling and guidance service increases, too. Thus, a teacher's attitude towards psychological counseling and guidance service cannot be considered as independently from his/ her professional self-esteem. So this result can be interpreted that teachers who develop a negative attitude towards psychological counseling and guidance service have also a low professional self-esteem.

It has been determined that there is a low, positive and meaningful relationship between teachers' attitude towards psychological counseling and guidance service and female gender. In other words, there are statistical differences between female and male teachers' attitude towards psychological counseling and guidance service. In some research, there are meaningful differences in teachers' attitude towards psychological counseling and guidance service in terms of genders while there are not any differences in the others. This can be based upon other variables besides gender.

It has been found that there is a low, positive, and meaningful relationship between teachers' positive attitude towards psychological counseling and guidance service and getting in-service training in psychological counseling and guidance. According to the results obtained from the research, as the teachers' consciousness level of psychological counseling and guidance service improves, they also develop positive attitudes to application. According to the results obtained from this research, it can be said that getting in-service training in psychological counseling and guidance for teachers is insufficient and it does not contribute enough to concerning thoughts and applications to psychological counseling and guidance services. Thus, it is considered as a requirement to increase in-service training in psychological counseling and guidance quantitatively as well as to improve them qualitatively.

According to the results obtained from the research, it has been found that there is not a meaningful relationship between teachers' attitude towards psychological counseling and guidance service and having a psychological counselor in his/ her school. In this context, it is a necessity to structure programs which satisfy the need for enough number of psychological counselors in order to meet the demand in schools. However, with the light of the results obtained from the research, it is understood that it is more important to improve the state qualitatively rather than quantitatively. 
In the research, it has been found that there is not a meaningful relationship between teachers' attitude towards psychological counseling and guidance service and their years of service. Similar to these results, in the research done by Demir and Can (2015), Öztürk (1999), Steward (1961) and Teker (2007), it hasn't been found a meaningful relationship between teachers' attitude towards psychological counseling and guidance service and their years of service. In contrast to these researches, Abbasoğlu (2014), McPhee (1985) and Pershing Demetropoulos (1981) proved that teachers having less experience have more positive attitude towards psychological counseling and guidance.

At the end of the research; the variables of professional self-esteem, gender and getting in-service training in psychological counseling and guidance are interrelated attitudes towards psychological counseling and guidance service with an intermediate meaningful relationship and it has been determined that the mentioned variables explain $\% 11$ of attitudes towards psychological counseling and guidance service. In addition, it has been found that only professional self-esteem and getting in-service training in psychological counseling and guidance among the predictor variables explain the attitude towards psychological counseling and guidance service meaningfully.

It is considered to contribute to the literature significantly when similar studies on this subject are carried out on a larger and different sample group including schools in different cities and different grades. In this context, more comprehensive research which explain teachers' attitude towards psychological counseling and guidance service and which consider professional self-esteem and variables except for the demographic variables as part of this research can be conducted. 